\title{
Paleogeographic evolution of the central segment of the South Atlantic during Early Cretaceous times: Paleotopographic and geodynamic implications
}

\author{
Chaboureau Anne-Claire 1, 2, Guillocheau François ${ }^{1,}{ }^{*}$, Robin Cecile ${ }^{1}$, Rohais Sebastien ${ }^{2}$, \\ Moulin Maryline ${ }^{3}$, Aslanian Daniel ${ }^{4}$
}

1 Univ Rennes 1, CNRS, Geosci Rennes UMR6118, F-35042 Rennes, France.

2 IFP Energies Nouvelles, F-92852 Rueil Malmaison, France.

3 Univ Lisbon, Fac Ciencias, IDL, P-1749016 Lisbon, Portugal.

4 IFREMER, Dept Marine Geosci, F-29280 Plouzane, France.

* Corresponding author : François Guillocheau, email address : francois.guillocheau@univ-rennes1.fr

\begin{abstract}
:
The geodynamic processes that control the opening of the central segment of the South Atlantic Ocean (between the Walvis Ridge and the Ascension FZ) are debated. In this paper, we discuss the timing of the sedimentary and tectonic evolution of the Early Cretaceous rift by drawing eight paleogeographic and geodynamic maps from the Berriasian to the Middle-Late Aptian, based on a biostratigraphic (ostracodes and pollen) chart recalibrated on absolute ages (chemostratigraphy, interstratified volcanics, $\mathrm{Re}-\mathrm{Os}$ dating of the organic matter).
\end{abstract}

The central segment of the South Atlantic is composed of two domains, with a two phases evolution of the pre-drift ("rifting") times: a rift phase characterized by tilted blocks and growth strata, followed by a sag basin. The southern domain includes the Namibe, Santos and Campos Basins. The northern domain extends from the Espirito Santo and North Kwanza Basins, in the south, to the Sergipe-Alagoas and North Gabon Basins to the north.

Extension started in the northern domain during the Late Berriasian (Congo-Camamu Basin to the Sergipe-Alagoas-North Gabon Basins) and migrated southward. At that time, the southern domain was not a subsiding domain (emplacement of the Parana-Etendeka Trapp). Extension started in this southern domain during the Early Barremian. The rift phase is shorter in the south (5-6 Ma, Barremian to base Aptian) than in the north (19 to $20 \mathrm{Myr}$, Upper Berriasian to base Aptian). The sag phase is of Middle to Late Aptian age. In the northern domain, this transition corresponds to a hiatus of Early to Middle Aptian age.

From the Late Berriasian to base Aptian, the northern domain evolves from a deep lake with lateral highs to a shallower organic-rich one with no more highs. The lake migrates southward in two steps, until the Valanginian at the border between the northern and southern domains, until the Early Barremian, north of Walvis Ridge. 


\section{Highlights}

- Age reevaluation of the basins $>$ Compilation of eight paleogeographic and deformation maps $>$ Two main domains with different deformation and sedimentary history Diachronous extension from north (Late Berriasian) to south (Early Barremian). Transition to brittle rift to sag during Early Aptian, with hiatus in the northern domain.

Keywords: South Atlantic Ocean - central segment, Rift, Early Cretaceous, Paleogeography, Geodynamic 
The South Atlantic Ocean results from the breakup of Gondwana into two continents, South America and Africa, during Early Cretaceous times. It can be divided into four segments (Moulin et al., 2005): the Falkland segment, south of the Agulhas-Falkland Fracture Zone (AFFZ), the southern segment from the AFFZ to the Rio-Grande FZ, the central segment from the Rio-Grande to the Ascension FZ, and the equatorial segment from the Ascension to the Marathon FZ (Fig. 1). characterized by a sag basin phase (Karner and Driscoll, 1999; Karner 60 et al., 2003; Lentini et al., 2010; Marton et al., 2000), prior to salt 61 deposition and oceanic accretion, and after a rift phase characterized 62 by blocks tilting in the upper continental crust. The sag basin (also 63 called pre-salt sag basin or pre-salt wedge) is characterized by a 64 thick wedge of sediments ( 3 to $5 \mathrm{~km}$ ), with no evidence of brittle 65 extension (tilted blocks with syn-sedimentary normal faults with a 66 wavelength of several kilometers to several tens of kilometers). It 67 looks like a large wavelength (several hundreds of kilometers) 68 "flexural" basin. In its proximal part, this sag basin onlaps the tilted 69 blocks mentioned above (Moulin et al., 2005).

This two steps evolution, with a rift phase with tilted blocks and 71 growth strata first and a sag phase second, does not fit with classical 72 


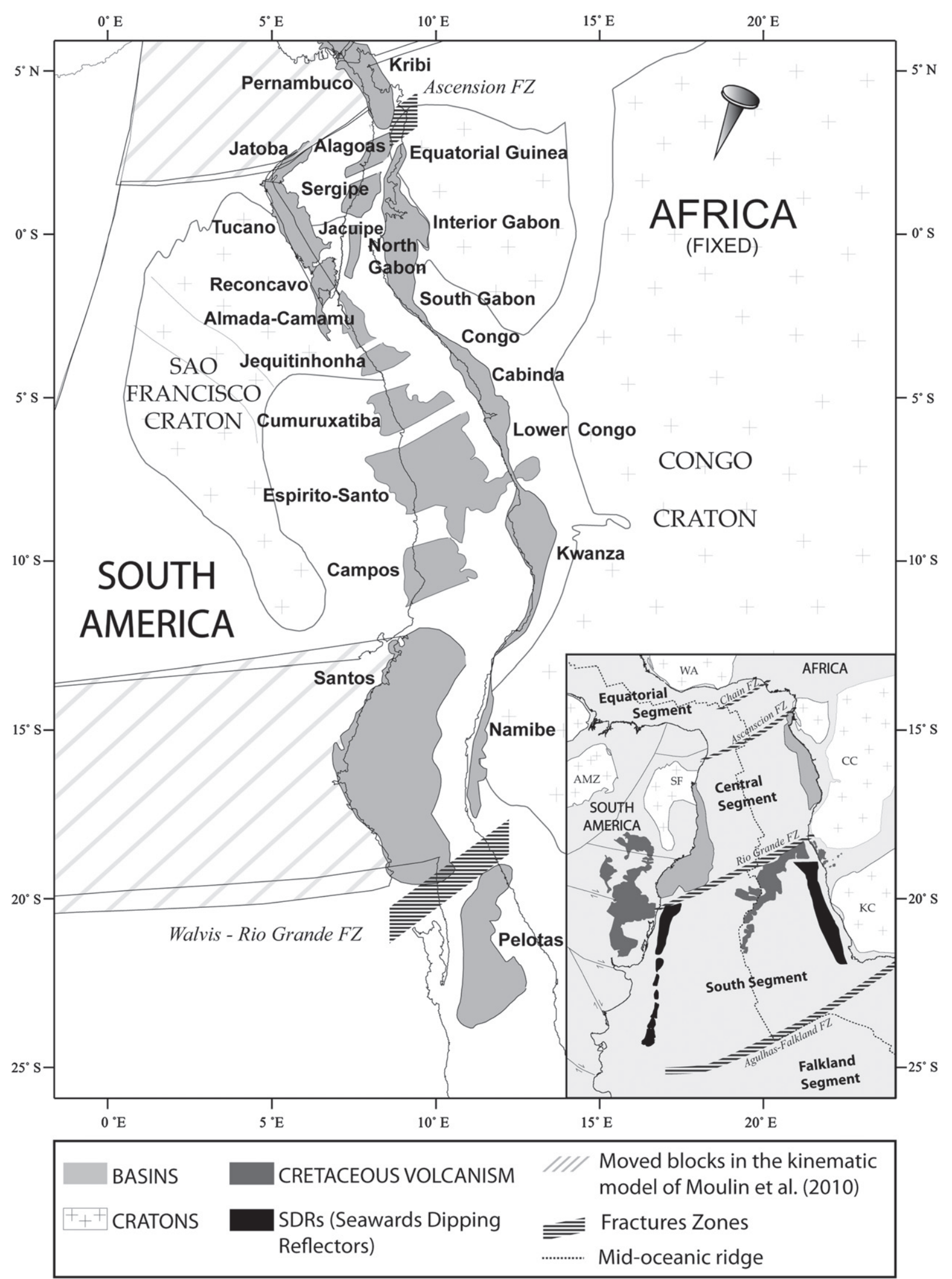

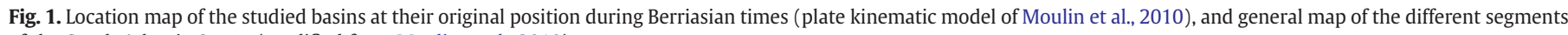
of the South Atlantic Ocean (modified from Moulin et al., 2010).

models of uniform lithospheric extension, pure shear (McKenzie, 1978) and simple shear (Wernicke, 1985) models. Thus, alternative depth dependent models were proposed. By applying the model of
Lavier and Manatschal (2006), with brittle layers within the lower 76 crust and the upper mantle, Unternehr et al. (2010) suggest a two 77 phases conservational model (the volume of continental crust at the 78 
79 end of the extension is strictly equal to the initial volume before any 80 horizontal movement) with (1) a thinning mode of the lithosphere 81 with brittle deformation and necking of the lower crust in the most 82 distal part and (2) an exhumation mode with denudation of the 83 upper mantle. Aslanian et al. (2009) proposed a non conservational 84 model in three phases, (1) extensive phase (called rift phase) with 85 few tilted blocks in the upper continental crust, (2) the exhumation 86 phase (with the sag formation and the salt deposition), main thinning 87 phase mostly involving the lower continental crust and (3) the 88 break-up and oceanic spreading stage. The Huismans and Beaumont's 89 model $(2008,2011)$, based on lithospheric numerical models with 90 depth-dependant extension, implies a weak lower crust, decoupling 91 layer between the crust and the mantle lithosphere, and, as a conse92 quence, a diachronism between the mantle and the upper crust 93 thinning. Those models did not agree on several points: the rheology 94 of the lithosphere (weak or strong), as well as the nature of the 95 exhumed material, the timing and the synchronicity of the extensional 96 period characterized by blocks tilting and the sag basin.

Except for the Aslanian's et al. model (2009), little attention is paid in those models to paleogeographic and paleotopographic constraints and consequences. The aim of this study is to establish the timing of the sedimentary and tectonic evolution of the central segment of the South Atlantic Ocean (Fig. 1), on both sides, during the Early Cretaceous, by drawing paleogeographic and geodynamic maps, in order to answer several questions: What is the age of the rift phase with block tilting and the sag periods? Do they overlap through time? If the exhumation models (Aslanian et al., 2009; Lavier and Manatschal, 2006) can be applied to this oceanic segment what is the age of this exhumation, time of denudation of the mantle and/or lower continental crusts?, How do the sedimentary environments of the rift and sag periods change? What are the surrounding reliefs and catchments?
During the evolution of the rifting (rift phase with tilted 142 blocks + sag), several authors (Guiraud and Maurin, 1991, 1992; 143 Magnavita et al., 2005; Matos, 1992, 1999) suggest variations in the 144 extensional direction, but they do not agree for the timing of these 145 changes. North of the Reconcavo-South Gabon Basins until the 146 Potiguar-Benue Basins, Matos $(1992,1999)$ suggests three changes, 147 EW to ESE-WNW (Early Berriasian), SE-NW (Late Berriasian to 148 Early Barremian) and again EW to ESE-WNW (Late Barremian), while 149 Magnavita et al. (2005) suggest two steps, E-W (Berriasian-Valanginian: 150 Rio da Serra stage) and SE-NW (Barremian-Aptian, Jiquia stage). At the 151 scale of Africa, Guiraud and Maurin $(1991,1992)$ show a major change 152 during the Aptian, between a NNE-SSW and an ENE-SSW direction. 153

While the volcanic nature of the austral segment of the South 154 Atlantic, characterized by the presence of seaward-dipping reflectors 155 (SDRs) - subaerial volcanic flows - is well established, the volcanic 156 nature of the margins of the South Atlantic central segment and 157 then the occurrence of seaward-dipping reflectors, are debated 158 (Blaich et al., 2011; Contrucci et al., 2004; Moulin et al., 2005; 159 Reston, 2010). SDRs were expected in the Sergipe and Gabon Basins 160 (Mohriak et al., 1995, 1998), and also southward in the Santos and 161 Campos Basins (Mohriak and Rosendahl, 2003, 2008). According to Q9 Q10 several authors (Blaich et al., 2010, 2011; Contrucci et al., 2004; 163 Moulin et al., 2005), the margins of the central segment are not 164 volcanic margins, because (1) if volcanism occurred locally, it is not 165 a major process for the formation of the margin compare to the 166 austral segment and (2) the subsalt geometries on the seismic lines 167 show structures very different from volcanic margins worldwide. 168

The time of first occurrence of the oceanic crust is highly debated, 169 and particularly the relationship with the salt. For the "post-breakup 170 salt" scenario, accretion occurred before salt deposition (Abreu, 1998; 171 Fonck et al., 1998; Guiraud and Maurin, 1992; Jackson et al., 2000; 172 Karner et al., 1997; Marton et al., 2000; Nürnberg and Müller, 173 1991). In this case, the salt basins of the African and Brazilian margins 174 were separated and deposited on a proto-oceanic crust. For the 175 "pre-breakup salt" scenario, seafloor spreading occurred after salt 176 deposition (Davison, 1999; Duval et al., 1992; Evans, 1978; Guardado 177 et al., 1990; Ojeda, 1982), and the substratum of the pre-salt sediment 178 infill would be continental or sub-continental (thinned continental 179 crust, intruded lower continental crust or exhumed mantle material, 180 Moulin et al., 2005).

The geochemical study of the fine-grained sediments of the 182 Congo by Harris (2000) and Harris et al. (2004) provides interesting 183 constraints on the paleoreliefs, paleoweatherings and paleolimnology. 184 Two phases are identified. The active rift (Sialivakou and Djeno, 185 Neocomian-Early Barremian) corresponds to narrow deep lakes 186 with restricted circulation and low $0_{2}$ levels and steep topography 187 on the rift sides with a weathering-limited soil profile and a low to 188 moderate flux of $\mathrm{CO}_{2}$. The late rift (Marnes Noires and Argiles vertes, 189 Late Barremian-Aptian) corresponds to broad shallow lakes with low 190 $\mathrm{O}_{2}$ levels in the water column and moderate topography on the rift 191 sides with an intermediate soil profile and a moderate to high flux 192 of $\mathrm{CO}_{2}$. This leads to the precipitation of carbonates and a large 193 increase of dissolved $\mathrm{SiO}_{2}$.

\section{Paleogeographic and geodynamic maps: method}

Paleogeographic and geodynamic maps were synthesized from 196 published data. They show, for time slices of a few millions years and 197 with South America and Africa in their position for each period, 198 (1) the distribution of the main facies (paleogeographic maps), from 199 alluvial fans to deep lacustrine environments (with indication of 200 the marine flooding) and (2) the location and the type of basin 201 (geodynamic maps). The three main limits of these maps are (1) the 202 heterogeneity of the data, (2) the age dating and (3) a dataset, limited 203 to the shallowest part of the present-day margin. 


\section{3.1. Dating}

Most of the pre-Albian sediments from the central segment of the South Atlantic are continental deposits. The fossils available for dating are ostracodes and pollen. Regional biozonations (Fig. 2) have been defined on both sides of the South Atlantic Ocean (Brazil, ReconcavoTucano-Jatoba is a reference: Moura, 1972, Africa: Grosdidier et al., 1996) and an equivalence for the ostracodes biozonations has been proposed by Bate (1999). The key question is the calibration of those regional scales on the international stratigraphic chart.

On the African side, the regional biostratigraphic scale (Fig. 2) has been established by the Elf biostratigraphers and published by Grosdidier et al. (1996): 11 ostracode biozones labeled from AS2 to AS13, 8 pollen biozones labeled from CII to CIX (Doyle et al., 1977, 1982), and 10 composite biozones (NE1 to NE 3, BA1 to BA 4 and AP1 to AP2) (Braccini et al., 1997). For the Brazilian basins, the regional biostratigraphic scale (Fig. 2) has been established by the Petrobras biostratigraphers (Moura, 1972) with 10 ostracode biozones (labeled from RT002 to RT009) and 28 ostracode subzones and 10 pollen biozones (from P120 to P270) (Arai et al., 1989; Regali et al., 1974). Schaller (1969) and Viana et al. (1971) proposed local stages for the Lower Cretaceous of the Brazilian margin: Dom Soao, Rio da Serra, Arato, Buracica, Jiquia and Alagoas. Because the synchronicity of the limits of those stages is questionable (Arai et al., 1989, charts published by Milani et al., 2007), this nomenclature was not applied here.

Because of the limited connections with the sea, the calibration of these regional biozonations with the standard international stratigraphic scale, based on marine faunas, is difficult and the arguments for the equivalences are not really discussed. Elf biostratigraphers (Braccini et al., 1997; Grosdidier et al., 1996) defined three stages
Neocomian, Barremian and Aptian, with uncertainties on the exact 234 location of the stage boundaries (Fig. 2). Braccini et al. (1997) proposed 235 absolute ages for the limits of the composite biozones that made 236 it possible to define the Berriasian, Valanginian and Hauterivian 237 stages. On the Brazilian side, the stratigraphic scale (local biozones 238 and international stages) was published by Feijo (1994) and Bueno 239 (2004). They do not agree on the limit of the stages with respect to 240 the same biozonations (Fig. 2).

We used the equivalence of the ostracode biozones proposed by 242 Bate (1999) to compare the ages on both sides of the Atlantic 243 (Fig. 2). They do not fit. The Berriasian-Valanginian boundary on 244 the Brazilian side is equivalent to the Lower-Upper Valanginian 245 boundary on the African side. The Hauterivian-Barremian boundary 246 on the Brazilian side is equivalent to the Lower-Upper Barremian 247 boundary on the African side.

This implies that new data must be obtained for an absolute 249 age calibration of these regional biozonations (Fig. 3). We compiled 250 (1) absolute ages available on volcanics interstratified with sediments 251 dated by ostracodes (Santos and Campos Basins) and on organic 252 matter-rich sediments (Re-Os dating technique, Creaser et al., 2008) 253 and (2) chemostratigraphical data (Bueno, 2004) and synthesized 254 them on the chart of the International Commission for Stratigraphy 255 published in 2009 (www:http//stratigraphy.org). Those data are only 256 available on the Brazilian side of the rift. For Re-Os datings, no error 257 bars on the ages are available.

The first level that can be dated correspond to the organic matter-rich 259 shales of the Rio da Serra Brazilian stage (Candeia Formation?) of the 260 Reconcavo Basin, ranging from ostracode biozones 002.2 to 003.2261 (intra AS3), at around $140 \mathrm{Ma}$ (Creaser et al., 2008, i.e. around the 262 Berriasian-Valanginian boundary).

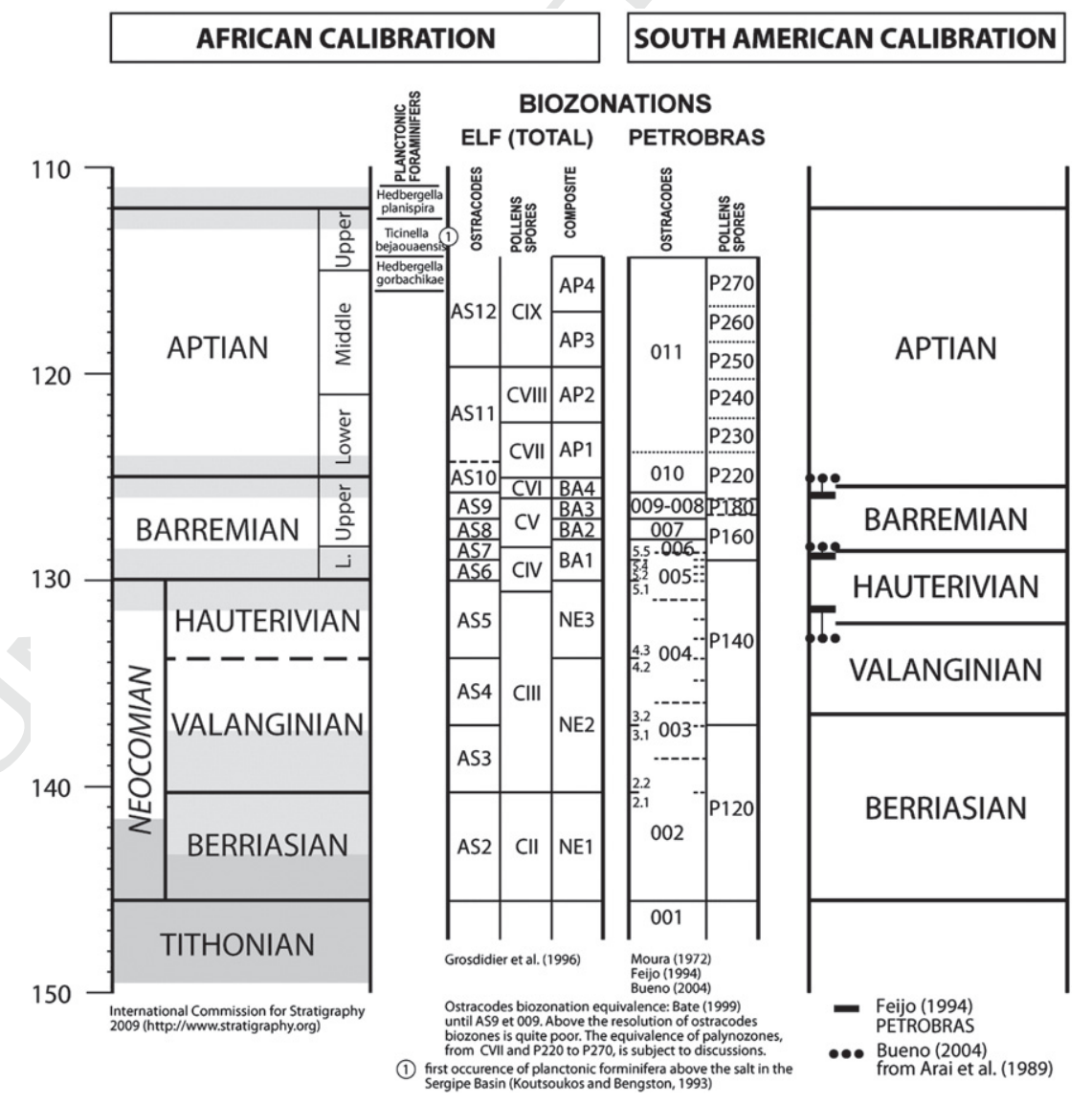

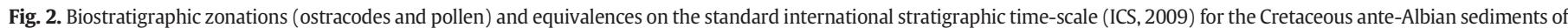

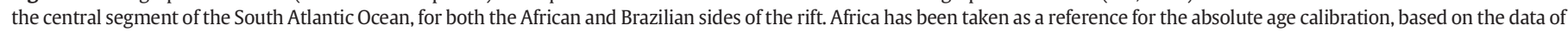
Braccini et al. (1997). 
Six main environments have been mapped based on the sedimentological or paleoeocological data available: open marine, hypersaline (salt), lacustrine (with turbidites, i.e. deep lake, shallow limestones, and organic matter-rich), deltaic, alluvial plain (distal, proximal) and alluvial fans. Alluvial plain deposits correspond to all the alluvial deposits that did not correspond to alluvial fans. Based on the grain size, two types of alluvial plains were defined: coarse-grained sediments should be deposits of bedload fluvial channels and finegrained sediments are those of mixed to suspended-load channels. Possible highs with no preserved sediments were also reported, as well as hiatuses.

The detailed maps are based on the present-day contours of the preserved sediments. Numerous data have been published for the African basins (e.g. Anderson et al., 2000; Bate et al., 2001; Braccini et al., 1997; Mbina Mounguengui and Guiraud, 2009; Mbina Mounguengui et al., 2008; Robert and Yapaudjian, 1990; Teisserenc and Villemin, 1990). For the Brazilian basins, we used both published sedimentological studies (e.g. Dias et al., 1988; Figueiredo et al., 1994; Rangel and Carminatti, 2000) and, when data are missing, facies data available on the detailed stratigraphic charts of Petrobras (Milani et al., 2007) are reported on the basin contours. For each map, the names of the mapped lithostratigraphic units are indicated.

Stratigraphic charts, with detailed facies evolution, were compiled for each basin (Fig. 5).

\subsection{Geodynamic maps: active tectonic structures, types of sedimentary} basins and volcanism

A deformation chart (Fig. 6) has been established. Four types of tectonic settings were defined: pre-rift stage, rift phase with tilted blocks and growth strata, sag and post-rift passive margin, with a focus on the rift and sag phases. Sag basins are recorded by flexural geometries with a wavelength of hundreds of kilometers, unconformably overlapping the tilted blocks of the underlying rift phase. It corresponds to the pre-salt wedge or pre-salt sag basin of Karner et al. (2003) and Karner and Driscoll (1999) and to the post-rift ante drift of Petrobras geologists (Milani et al., 2007). These data were put back onto the previously established stratigraphic chart (Fig. 4).

This chart is based on published papers (Brazilian side: Petrobras charts, African side: Robert and Yapaudjian, 1990; Teisserenc and Villemin, 1990) or on the interpretation of published sections (e.g. Dyer, 2008 for the Santos Basin; Braccini et al., 1997 for the Cabinda Basin).

\section{Stratigraphic and deformation charts: main limits}

\subsection{Stratigraphic charts (Fig. 4)}

Biostratigraphic data are not available for three basins: the Lower Congo, Namibe and Santos Basins. The lithostratigraphy of the Lower Congo Basin (Anderson et al., 2000) is the same as the one applied in Cabinda. We extended the Cabinda lithologies and environments to the Lower Congo. The knowledge of the Namibe Basin is more critical, because only one publication (Coterill et al., 2002) is available for this key area. We therefore used Coterill's data on the chart; these data indicate a different evolution of the Namibe Basin compared to the conjugate Santos Basin. This means either (1) a specific tectonic setting of this basin compared to the Santos Basin (Moulin et al., 2012) or (2) an error in the age attribution of the volcanics (Neocomian-Barremian boundary) by Coterill et al. (2002) that could be younger than expected. In fact, these volcanics could be of the same age as the ones of Late Cretaceous (bounded by sediments of Turonian and Campanian ages) cropping out onshore on the Mossamedes Basin (Carvalho, 1961). Because the age attribution and the stratigraphic sequence pattern of the Santos Basin (Moreira et al., 2007) are similar to those of the Campos Basin (Winter et al., 379 2007), the age of the different formations of the Santos Basin is 380 deduced from the Campos Basin, where biostratigraphic data are 381 available.

382

Some basins have incomplete or contradictory biostratigraphic 383 datasets. For the Kwanza Basin, some ostracode biozones were not 384 formally identified (AS3-4 for the Falçao Limestones and AS3-5 for 385 the Lukunga shales), and a continuity of sedimentation is assumed 386 with the underlying Lukunga Sandstones (AS2) by Bate et al. 387 (2001), from AS2 to AS5. An alternative interpretation could be a 388 hiatus of AS3-4 and AS3-5. In the same area, Bate et al. (2001) 389 suggest, in a figure, a hiatus that is not discussed in the text. This is 390 why we have considered two different scenarios for the Kwanza 391 Basin. For the Cabinda and Campos Basins, several contradictory 392 studies on the lithostratigraphic interpretation have been carried 393 out (Cabinda Basin: Braccini et al., 1997; Karner et al., 2003; 394 McHargue, 1990; Campos Basin: Rangel and Carminatti, 2000; 395 Q13 Winter et al., 2007). In both cases, we kept those for which biostrati- 396 graphic and geological data (wells correlation and geometries) were 397 published (Cabinda Basin: Braccini et al., 1997; Campos Basin: 398 Rangel and Carminatti, 2000).

The early stages of deposition of some late subsiding basins are 400 subjects to discussion. No data are available for the age of the base 401 of the Jequitinhonha Basin, dated by comparison with the Espirito 402 Santo and Almada-Camamu Basins. Another key question is the age 403 of the North Gabon Basin (Teisserenc and Villemin, 1990) and then 404 the possible occurrence of sediments older than the N'Toum-Bikele 405 Fm (biozone AS9-11, Teisserenc and Villemin, 1990) that could be 406 equivalent to the lower part of its twin basin, the Jacuipe Basin. $\quad 407$

We characterized a hiatus of variable duration through space dur- 408 ing the Early-Middle Aptian, except in the Santos Basin. This hiatus is 409 well known on the African side (work by Elf biostratigraphers) and 410 has been defined here on the Brazilian side based on biostratigraphic 411 data published by Petrobras in 1994 (Netto et al., 1994; Santos et al., 412 1994; Vieira et al., 1994). Our interpretation is slightly different than 413 that published by Petrobras in 2007 (Milani et al., 2007), for which 414 biostratigraphic data are not available. Nevertheless, our interpreta- 415 tion is highly dependant of (1) better intercorrelation between the 416 African and Brazilian pollen biozone for Aptian times (dash line 417 Fig. 2 and 4) and (2) a better calibration on the International Strati- 418 graphic Chart.

\subsection{Deformation charts (Fig. 6)}

Few data are available for the Kwanza and Namibe Basins. The chart 421 is based on the sections and chart published in (1) Marton et al. (2000) 422 that identified three steps in the Kwanza Basin (a pre-rift - the Lucula 423 Fm of the same age as the Lukunga Fm, see Fig. 4 - a rift and a sag 424 phase - Cuvo Fm) and (2) Coterill et al. (2002) for the Namibe Basin. 425

The beginning of the rift is discussed in both the Cabinda and 426 Sergipe-Alagoas Basins. In the Cabinda Basin, based on the section 427 published by Braccini et al. (1997) and the sections published by 428 Marton et al. (2000), the rift clearly started after the deposition of 429 the Lucula Fm. For the Sergipe-Alagoas Basin, published sections, 430 limited to the upstream part of the basin (Borba et al., 2011; 431 Chiossi, 2005), suggest an age younger than that published by 432 Petrobras (Campos Neto et al., 2007).

The tectonic setting of the volcanics of the Santos and Campos Basins 434 (Cabuinas and Camboriu Fm) is unclear, with lava flooding prior to or at 435 the same time as the extension (occurrence of syn-sedimentary normal 436 faults during the volcanics)?

Some authors have identified several periods with different 438 extension rate and direction. Those can change within the same 439 basin (e.g. Cabinda Basin, Braccini et al., 1997) or are subject to high 440 age uncertainties (e.g. Almada-Camamu Basin, Scotchman and 441 Chiossi, 2009). 

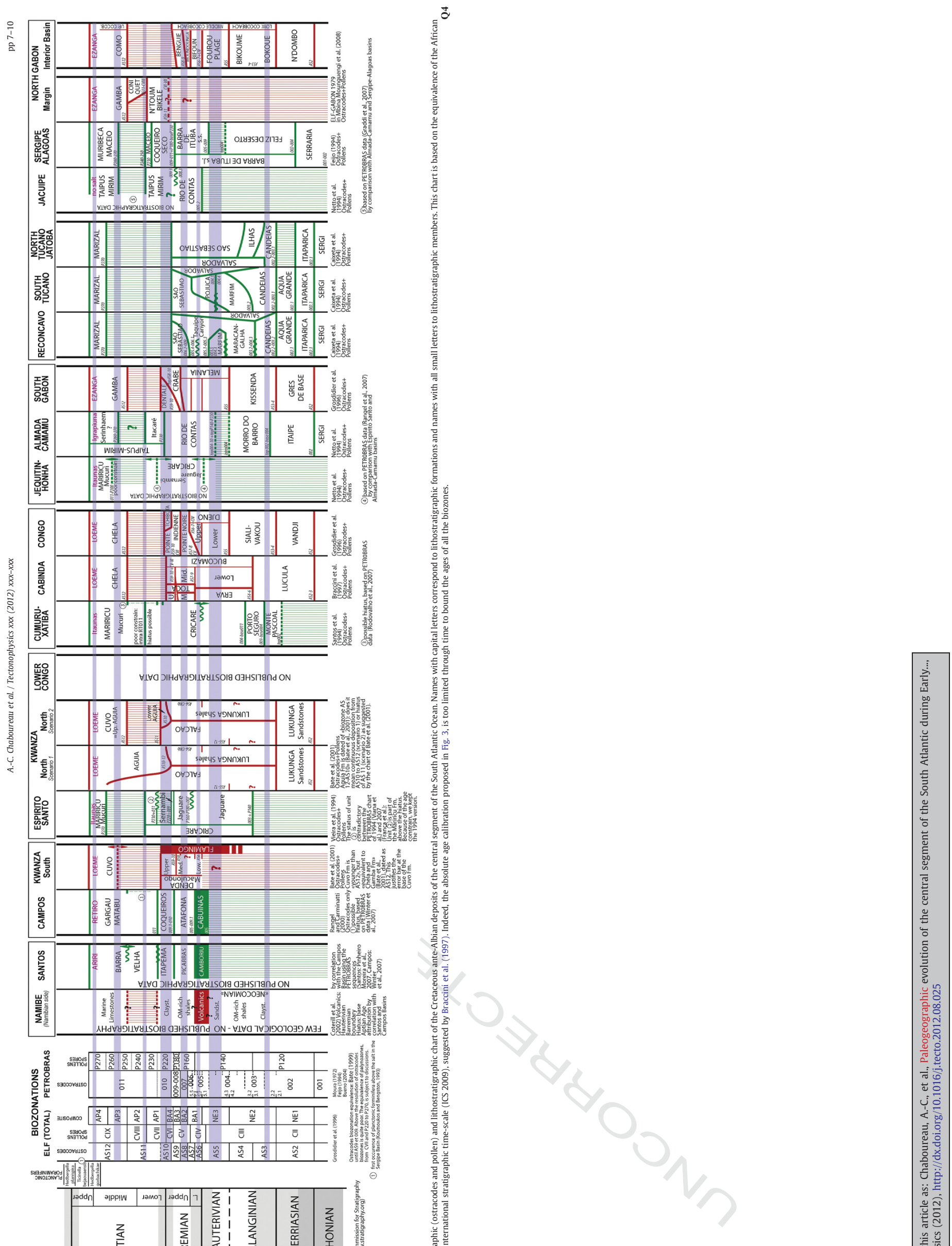


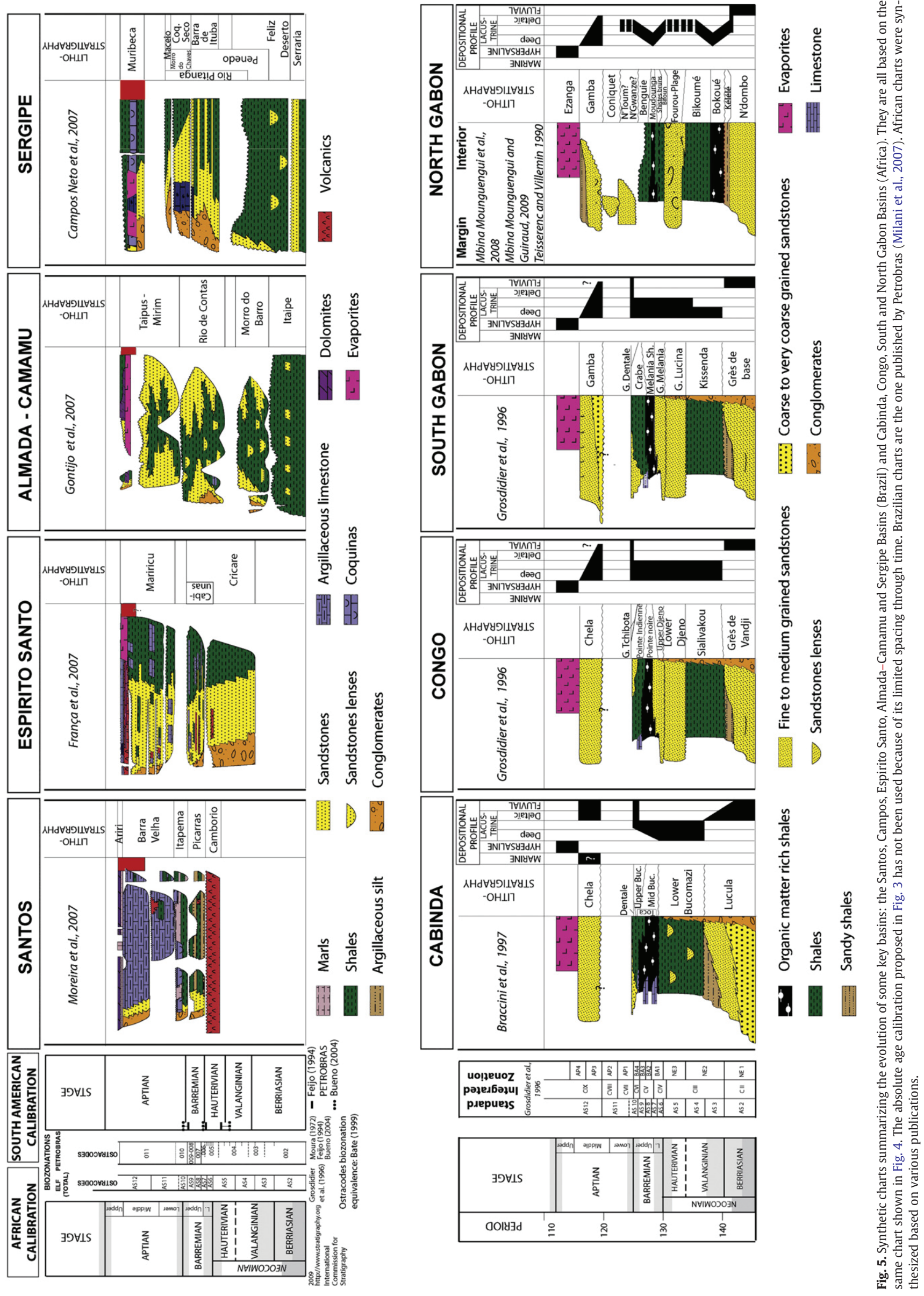


n some rifts, it is difficult to decipher between real syndimentary faults, post-depositional faults with no growth strata and clear gravity tectonics due to a regional tilting and/or an increase of the sediment supply. Gravity tectonics seems very important in two aborted rifts: the Reconcavo-Tucano-Jatoba rift (decollement level: Candeias Fm, Cupertino and Bueno, 2005; Magnavita et al., 2005) and in the Gabon Interior rift (decollement level: Bokoue and Bikoume Fm, Mbina Mounguengui et al., 2008). It is, in both cases, very difficult to characterize the periods of crustal brittle extension.

\section{Paleogeographic and geodynamic maps}

\subsection{Berriasian-Valanginian boundary (intra ostracode biozone AS3):} 141-139 Ma

\subsubsection{Paleogeography}

Two domains can be defined bounded by the North Abrolhos "Fracture Zone" (present-day boundary between the Espirito Santo and Cumuruxatiba Basins), diffuse zone of deformation along numerous minor faults over a large area, rather than on major localized faults (Fig. 7).

Southward, no deposit occurred except, with doubt, the Namibe Basin and the North Kwanza Basin: these two key areas were not biostratigraphically dated of biozone AS3 (see discussion above).

Northward, the sedimentary setting was a deep lake bordered with alluvial fans, except for the Cumuruxatiba Basin (southwestern limit of the depositional domain), where alluvial plain sediments were deposited. Some areas are devoid of sediments: Jequitinhonha (between the Cumuruxatiba and Camamu Basins), Jacuipe and its conjugated domain, the North Gabon Basin.

The published stratigraphic and facies charts of the CamamuAlmada Basins (Caixeta et al., 2007; Gontijo et al., 2007) indicate a double supply, from the west and from the east, of these basins. The eastward feeding suggests the occurrence of a continental high that could be the southern extension of the Jacuipe-North Gabon non depositional domain. This questions the existence of a single lake or of two lacustrine systems, a first one from the Jatoba Basin to the Almada-Camamu Basin and a second one from the Sergipe-Alagoas Basins to the Kwanza Basin. We have no argument for choosing between those two scenarios.

Alluvial fans seems limited to the African side (Braccini et al., 1997; Grosdidier et al., 1996; Teisserenc and Villemin, 1990), except along the Camamu-Almada upstream border (Caixeta et al., 2007; Gontijo et al., 2007). This absence on most of the Brazilian side could suggest basins larger than the present-day preserved rifts.

Turbiditic systems were identified as channels in the CamamuAlmada (charts of Caixeta et al., 2007; Gontijo et al., 2007), Reconcavo (Silva et al., 2007), Tucano-Jatoba (chart of Costa et al., 2007) and Sergipe-Alagoas Basins (chart of Campos Neto et al., 2007). On the African side (South Gabon and Congo), the deep lake is mainly shaley with few sands (Kissenda and Sialivakou Fm, Robert and Yapaudjian, 1990; Teisserenc and Villemin, 1990).

\subsubsection{Deformation}

Two parallel rifts are active in the northern domain, one westward from the Camamu-Almada Basin to the Jatoba Basin and a second one eastward from the Congo-Cabinda Basin to the Sergipe-Alagoas Basins, crossing through the Gabon interior Basin. The eastern branch could extend southward to North Kwanza. These two rifts are separated by a high that corresponds to the place of sedimentary hiatus discussed above, here called the Central Elevated Block (CEB). The Cumuruxatiba Basin is not yet a rift, but instead is a pre-rift "sag" basin.

\subsubsection{Paleogeography}

Two domains can be defined bounded by the Luanda FZ (Fig. 8). 505

Southward, no deposit occurred except along the Namibe Basin 506 where dating is uncertain.

Northward, the sedimentary setting was a large deep lake with 508 widespread turbiditic systems. The Espirito Santo and North Kwanza 509 Basins are subsiding domains. The Jacuipe and North Gabon areas are 510 still not depositional. Petrobras data (Caixeta et al., 2007; Gontijo 511 et al., 2007) again indicate a double supply of the Camamu-Almada 512 Basins from a possible southward continental extension of the 513 Jacuipe-North Gabon domain (CEB). Again the question of the 514 connectivity of the Camamu-Almada, Reconcavo, Tucano, and Jatoba 515 Basins with the rest of the lake is addressed. The age of the beginning 516 of sedimentation in the Jequitinhonha Basin is uncertain and can be of 517 this time period. If it is right, because of the lacustrine nature of the 518 first sediments in the Jequitinhonha Basin (Cricaré Fm), such a 519 connection makes sense. The North Kwanza Basin is the first setting 520 of lacustrine limestones.

Alluvial fans are recorded all along the rift from the Espirito Santo 522 Basin to the Jatoba Basin, on the Brazilian side, and from the Lower 523 Congo to South Gabon Basins on the African side. There are no alluvial 524 fans in the Cumuruxatiba and Jequitinhonha Basins, the Alagoas Basin 525 (post-deposition erosion?) and the Interior Gabon Basin. No informa- 526 tion is available for alluvial fans in the North Kwanza Basin. Alluvial 527 plain deposits are mainly located on the Brazilian side, in the Espirito 528 Santo and Cumuruxatiba Basins, but also in the Jatoba and Tucano 529 Basins (beginning of the infilling by subaerial deposits).

On the African side, this is the time of coarse-grained turbiditic 531 deposition (Congo: Djeno Fm, Lower Mbr, debris flows and grain 532 flows, Robert and Yapaudjian, 1990; South Gabon: Lucina Fm, channel 533 and lobe deposits, Teisserenc and Villemin, 1990; Interior Gabon: 534 Fourou Plage Fm, Teisserenc and Villemin, 1990) and finer-grained 535 equivalents (Cabinda: Bucomazi Fm, Lower Mbr, Braccini et al., 1997). 536

\subsubsection{Deformation and volcanism}

The rift is located northward of the Luanda FZ. This single rifting 538 splits into two branches from the Camamu and South Gabon Basins 539 separated by the CEB.

The southern domain records the early stages of the Parana- 541 Etendeka volcanic event, mainly located onshore in Brazil. The Santos 542 and Campos Basins are free of volcanics, except for some dyke swarm 543 around Rio de Janeiro and Vitoria-Trinitade (Guedes et al., 2005; 544 Novais et al., 2004). The Espirito Santo (França et al., 2007) and 545 Central Kwanza Basins (Bate et al., 2001) are time equivalents of 546 basalt lava flows and volcanoclastics.

\subsection{Around the Hauterivian-Barremian boundary (intra ostracode 548} biozone AS6): 131-129 Ma

\subsubsection{Paleogeography}

Two domains can be defined bounded by the Benguela FZ (Fig. 9). 551

Deposition occurred north of this FZ, except for the Campos Basin 552 where volcanism is observed. This northern domain is again a large 553 deep lake. The northwestern branch (from Camamu to Tucano 554 Basins) is connected to the great lake. The CEB is still a high (double 555 supply of the Camamu-Almada Basins, no sedimentation in the 556 North Gabon Basin) and seems to be an island. But its size is smaller 557 with the beginning of sedimentation in the Jacuipe Basin (Graddi 558 et al., 2007).

Turbiditic systems are still active on the African side (Congo: 560 Djeno Fm, Upper Mbr, Robert and Yapaudjian, 1990; South Gabon: 561 Melania Fm, Teisserenc and Villemin, 1990); however, they are 562 more fine-grained around the Cabinda Basin (Bucomazi Fm, Lower 563 Mbr; Braccini et al., 1997) and they do not exist in the Gabon Interior 564 


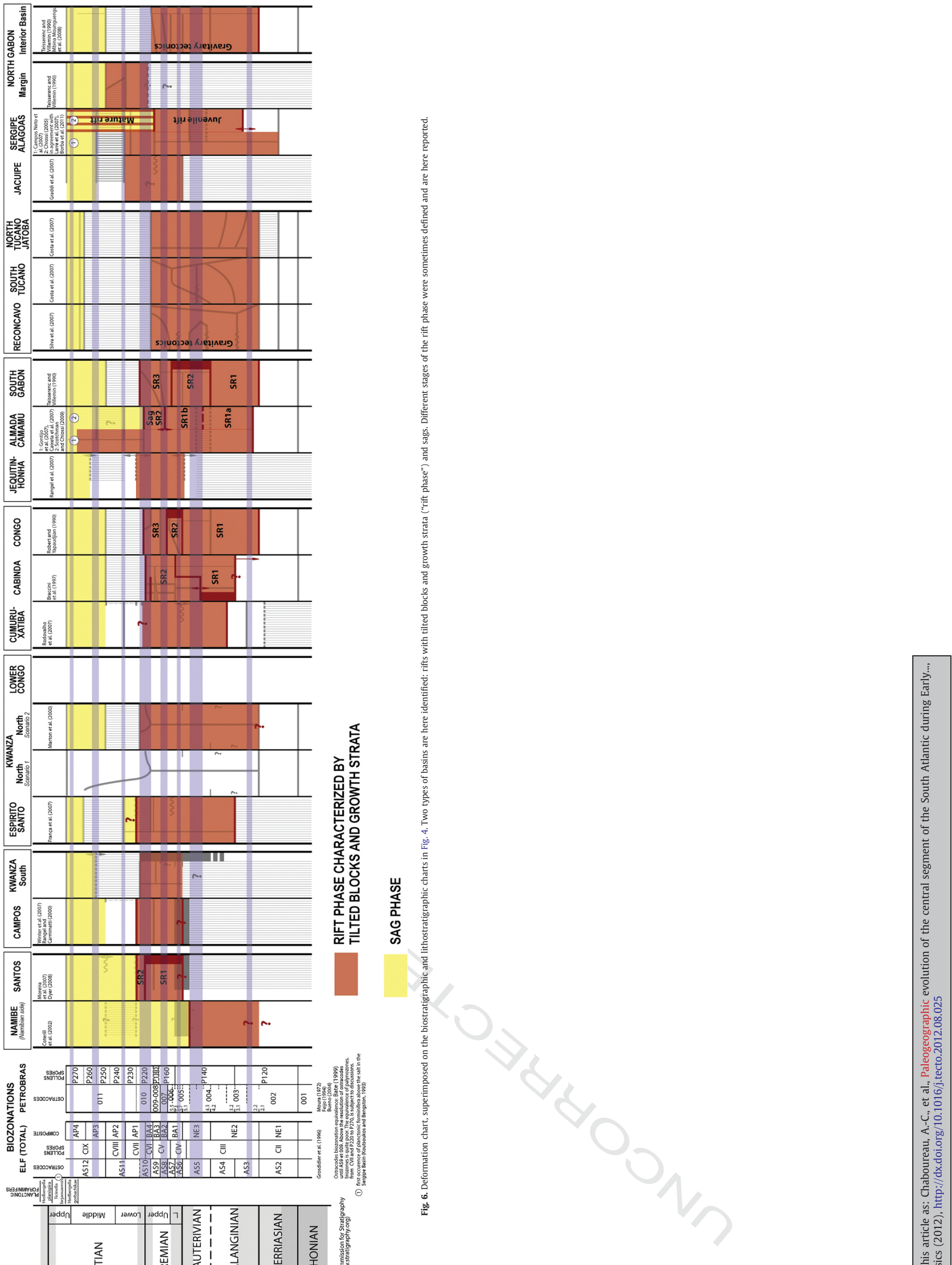




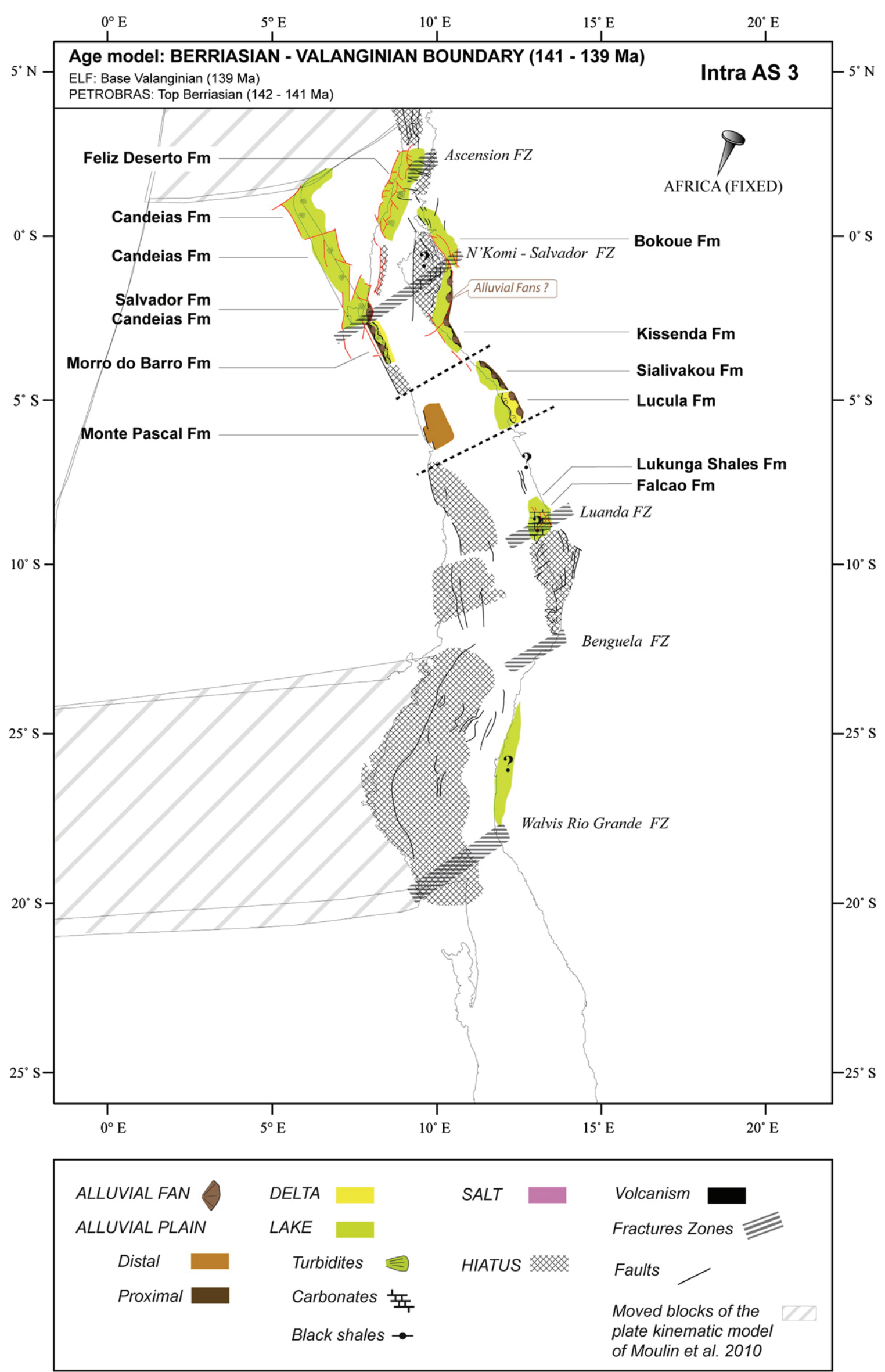

Fig. 7. Paleogeographic map at the Berriasian-Valanginian boundary (intra ostracode biozone AS3) - 141-139 Ma. 


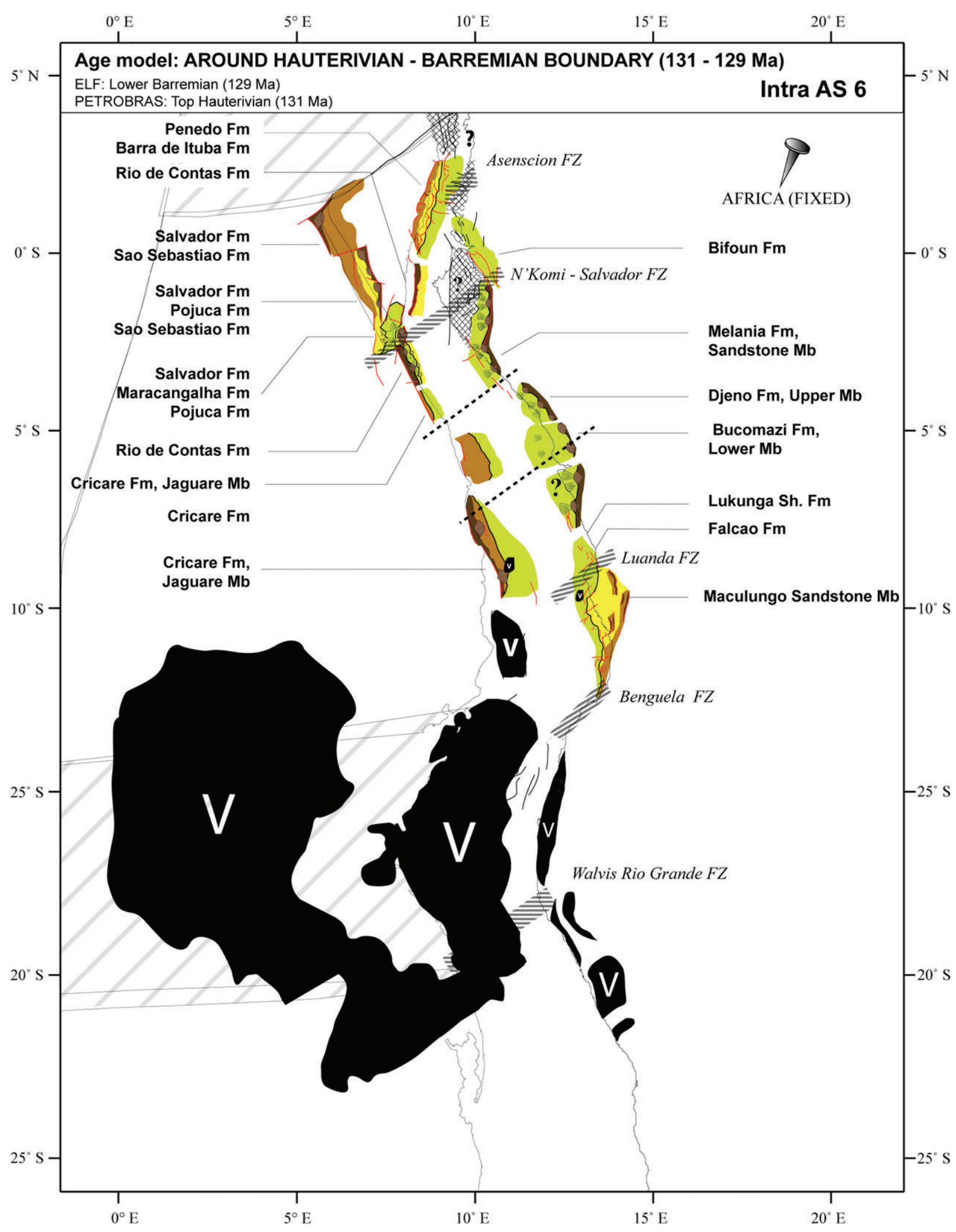

Fig. 9. Paleogeographic map around the Hauterivian-Barremian boundary (intra ostracode biozone AS6) - 131-129 Ma.

Almada Basins that split themselves into two subbranches, the TucanoJatoba and Jacuipe-Sergipe Basins.

This is the time of widespread volcanism from the Parana Basin to northern Namibia, including the Santos (Camboriu volcanics), Campos (Cabuinas volcanics) and Namibe Basins. This time interval corresponds to the paroxysm of the Parana-Etendeka Trapp (see age synthesis in Moulin et al., 2010).
5.4. Upper Barremian (ostracode biozone AS8): 128-126 Ma

\subsubsection{Paleogeography}

For the first time, deposition occurred all along the South Atlantic cen- 585 tral segment, from Walvis-Rio Grande to the Ascension FZs. The Central 586 Elevated Block (CEB) is still an island (double supply of the Camamu- 587 Almada Basins, no sedimentation in the North Gabon Basin) (Fig. 10). 588 


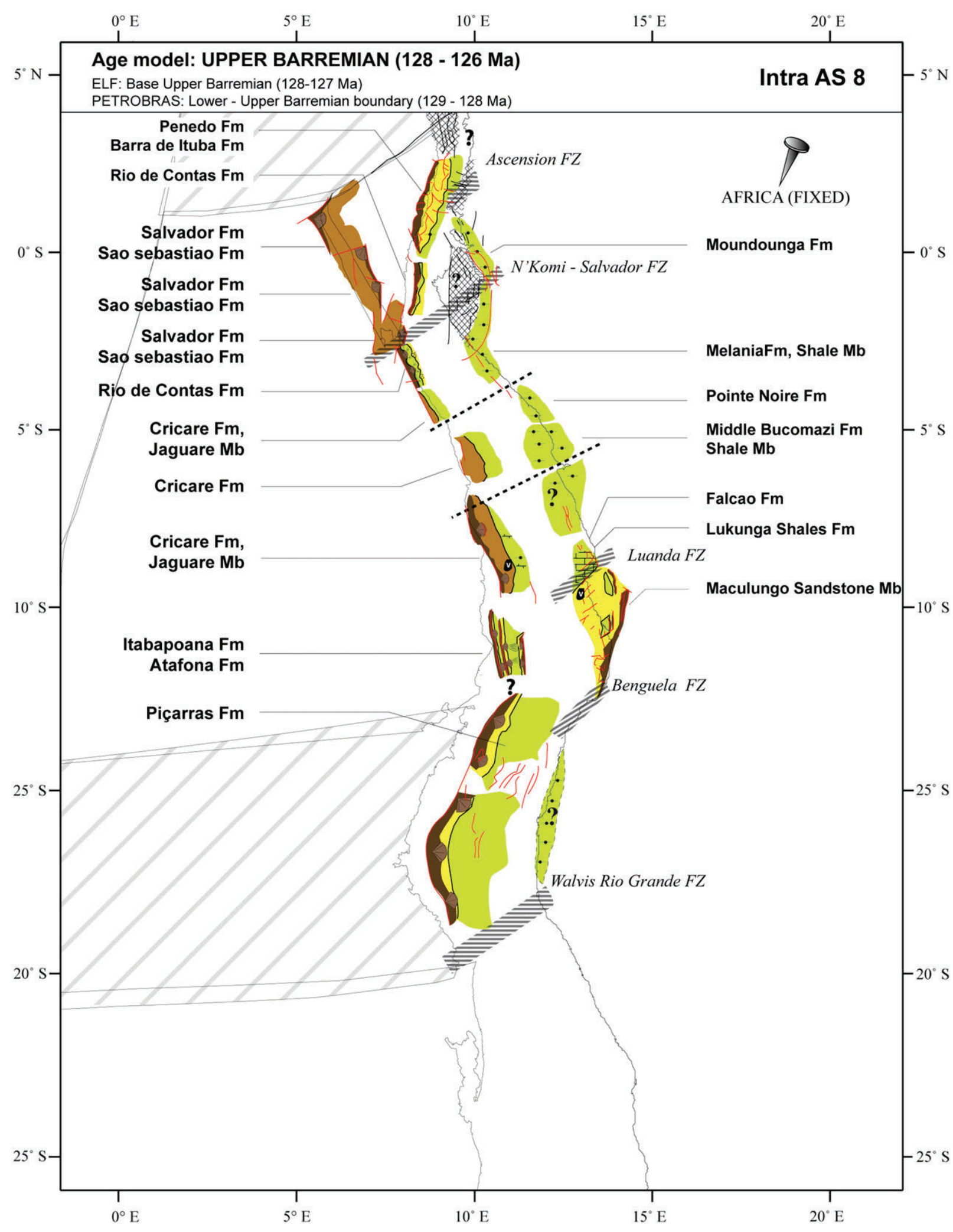

Fig. 10. Paleogeographic map at the Upper Barremian (ostracode biozone AS8) - 128-126 Ma.

This period records a major paleogeographic change that starts during ostracode biozone AS7 with two clear domains, north and south of the axis Campos to South Kwanza Basins. North, the lake is becoming shallower (Grosdidier et al., 1996) with organic-rich facies (Burwood et al., 1992; Gonçalves, 2001; Mello et al., 1988) and no turbidites. Alluvial fans are limited to the Brazilian side, from the Espirito Santo Basin to the Jatoba Basins (except the Cumuruxatiba and the Jequitinhonha Basins). This suggests an asymmetry of the 596 rift, with low relief on the African side. South, a deep lake occurred 597 with turbidites in the Campos Basin (Rangel and Carminatti, 2000; 598 Q15 Rangel et al., 1994). Alluvial fans are located along the Santos 599 (Moreira et al., 2007) and Campos (Rangel et al., 1994; Winter et al., 600 2007) Basins. Organic-rich sediments were possibly deposited in the 601 Namibe Basin (Coterill et al., 2002). 


\section{5.4.2. Deformation}

\subsubsection{Deformation} part of the rift. (Fig. 12).
Rifting is active all along the South Atlantic central segment, from Walvis Rio Grande to the Ascension FZs, with two different settings: very active in the south and more quieter in the North. In the south, alluvial fans are active and tilting of the blocks is well recorded in the Campos Basin. In the north, the three northern branches are still active, but the relief (rift shoulders and the water depth contrast) is not as well marked.

\subsection{Lower Aptian (ostracode biozone AS10): 124-123 Ma}

\subsubsection{Paleogeography}

The South Atlantic central segment looks like a single lake, with some short marine influences, subdivided into three domains: south (northern limit: the axis North Campos to South Kwanza Basins), central (from the Espirito Santo-North Kwanza Basins to the Jequitinhonha-Congo Basins) and north domains (Fig. 11).

The southern domain (mainly the Santos and Campos Basins) is made of a shallow-water alternation of clays and bioclastic limestones (bivalves coquinas, Carvalho et al., 2000a, 2000b; Moreira et al., 2007; Rangel and Carminatti, 2000), with upstream alluvial fans (Santos, Campos Basins). Evaporites (mainly salt, few anhydrites) occurred just before this time interval (ostracode biozone AS9) in the South Kwanza Basin (Bate et al., 2001).

The central domain shows the same shallow mixed lacustrine siliciclastic-limestone deposits (bivalves coquinas: Sernambi Fm in the Espirito and Jacuipe Basins, Toca and Banio Fm located on the highs of tilted blocks or as condensed levels in progradational geometries in the Gabon, Congo and Cabinda Basins, Braccini et al., 1997; Harris, 2000; Harris et al., 1994; Robert and Yapaudjian, 1990).

The northern domain is characterized by a major reorganization of the depositional areas: the Reconcavo, Tucano-Jatoba and the Gabon Interior Basins are no longer accumulative, but deposition clearly occurred in the North Gabon Basin (Bikele and N'Toum Fm, Mbina Mounguengui et al., 2008). Nevertheless, the CEB still exists as suggested by the double eastward and westward supply of the Camamu-Almada Basins and the paleocurrents pattern toward the NE in Gabon (Dentale Fm, Smith, 1995). This northern domain is either locally deep, as suggested by turbiditic deposition (Mbina Mounguengui and Guiraud, 2009; Mbina Mounguengui et al., 2008; Teisserenc and Villemin, 1990) or shallow (shallow bioclastic limestones in the Sergipe-Alagoas Basin, Campos Neto et al., 2007).

Alluvial fans are limited to the southern domain. Marine flooding is recorded (see discussion below) in the Sergipe Basin (fish, Gallo, 2009), South Gabon Basin (marine ostracodes, Grosdidier, 1967), Kwanza Basin (marine ostracodes, Bate, 1999 in Davison and Bate, 2004) and in the Campos Basin (benthic and planktonic foraminifera, Silva-Telles Jr., 1996 in Dias, 2005).

Rifting is active all along the South Atlantic central segment, the southern domain is still more active than the central and northern domains, as suggested by the alluvial fans. The Reconcavo, TucanoJatoba, and Gabon Interior Basins are no longer subsiding domain; however a new place of deposition, the North Gabon Basin has been created. This could mean deformation reorganization in the northern

This period looks like a transition toward a new tectonic setting

\subsection{Lower Aptian? (intra ostracode biozone AS11): 123-121 Ma}

\subsubsection{Paleogeography}

A major hiatus characterized this time period, excepted for the Santos and North Gabon Basins. The duration of this hiatus is variable through space, as is the age of its beginning and its end (see Fig. 4).
The shallow lake of the Santos Basin is characterized by mixed 664 siliciclastic-carbonate sediments, from alluvial fans to microbial lime- 665 stones (with stromatolites) with some clay layers (Moreira et al., 666 2007). The North Gabon Basin is continental, fluvial to deep lacustrine 667 sedimentation, as suggested by turbidite deposition (Coniquet Fm, 668 Teisserenc and Villemin, 1990).

\subsubsection{Deformation}

Two different domains can be defined: Santos Basin in the south 671 and all other basins toward the north. The southern domain is no 672 longer a rift. It is a large flexural domain, typical of a sag basin, with 673 local volcanism (Moreira et al., 2007). The possible tectonic meaning 674 of the hiatus will be discussed later, but normal faults are active 675 along the only domain in sedimentation (North Gabon Basin, Mbina 676 Mounguengui and Guiraud, 2009).

\subsection{Middle Aptian? (intra biozone AP3): 119-116 Ma}

678

The width of the South Atlantic segment is becoming the largest. 679 Because most of the well data available are limited to the present 680 day upstream part of the margin, our knowledge of the axial 681 (deepest) part of the basins is poor (Fig. 13).

\subsubsection{Paleogeography}

Again the central segment of the South Atlantic is subdivided into 684 two domains: the Santos and Campos Basins are mainly shallow 685 carbonate lakes, whereas the north is only siliciclastic deposits. 686

The limestones of the Campos and Santos Basins are similar to the 687 limestones of the previous period. They pass laterally to proximal 688 alluvial plain deposits (Moreira et al., 2007; Winter et al., 2007). 689 Toward the north, the rift is more asymmetric, with mainly alluvial 690 deposits in Africa and lacustrine to deltaic with few alluvial plain 691 deposits in Brazil (Fig. 5). The CEB is still a high, but is smaller, with 692 a double supply of the Camamu-Almada Basins, where alluvial fans 693 are still active on the Brazilian side (Gontijo et al., 2007).

Evaporites (halite) probably occurred at that time (pollens 695 biozones P230 à P260, Souza-Lima, 2008) in the Alagoas Basin. Ma- 696 rine flooding is expected in the Cabinda Basin on the basis of ostra- 697 codes (Braccini et al., 1997).

\subsubsection{Deformation}

All the basins of the South Atlantic central segment are flexural 700 sags (see Fig. 6 for references). Local normal faults can be locally 701 active or shortly reactivated during this period (Bib-FG). North of 702 the Sergipe-Alagoas Basins, subsidence starts in the Pernambuco 703 Basin (Feijo, 1994).

\subsection{Middle-Upper Aptian boundary (intra biozone AP4): 116-114 Ma 705}

For the same reasons as the Middle Aptian time slice, the nature of 706 the sediments of the axial part of the basins is poorly known and 707 questions the occurrence of evaporites and their relationships with 708 a possible oceanic ridge (Fig. 14).

\subsubsection{Paleogeography}

The entire South Atlantic central segment is covered by evaporites, 711 except in the Jacuipe, Alagoas and Pernambuco Basins, where 712 siliciclastic deposition occurred (Fig. 15).

Evaporites located in the southern part of the South Atlantic 714 central segment (Santos and Campos Basins) are mainly composed 715 of anhydrite and halite (Davison, 2007; Rangel and Carminatti, 716 Q19 2000). Sylvite and carnaillite are reported as a rare occurrence in 717 the Campos Basin (Rangel and Carminatti, 2000).

The northern part is mainly characterized by chloride evaporitic 719 minerals (sylvite, carnaillite and bischofite). The Gabon, Congo and 720 Sergipe Basins show potassium and magnesium chlorides, such as 721 


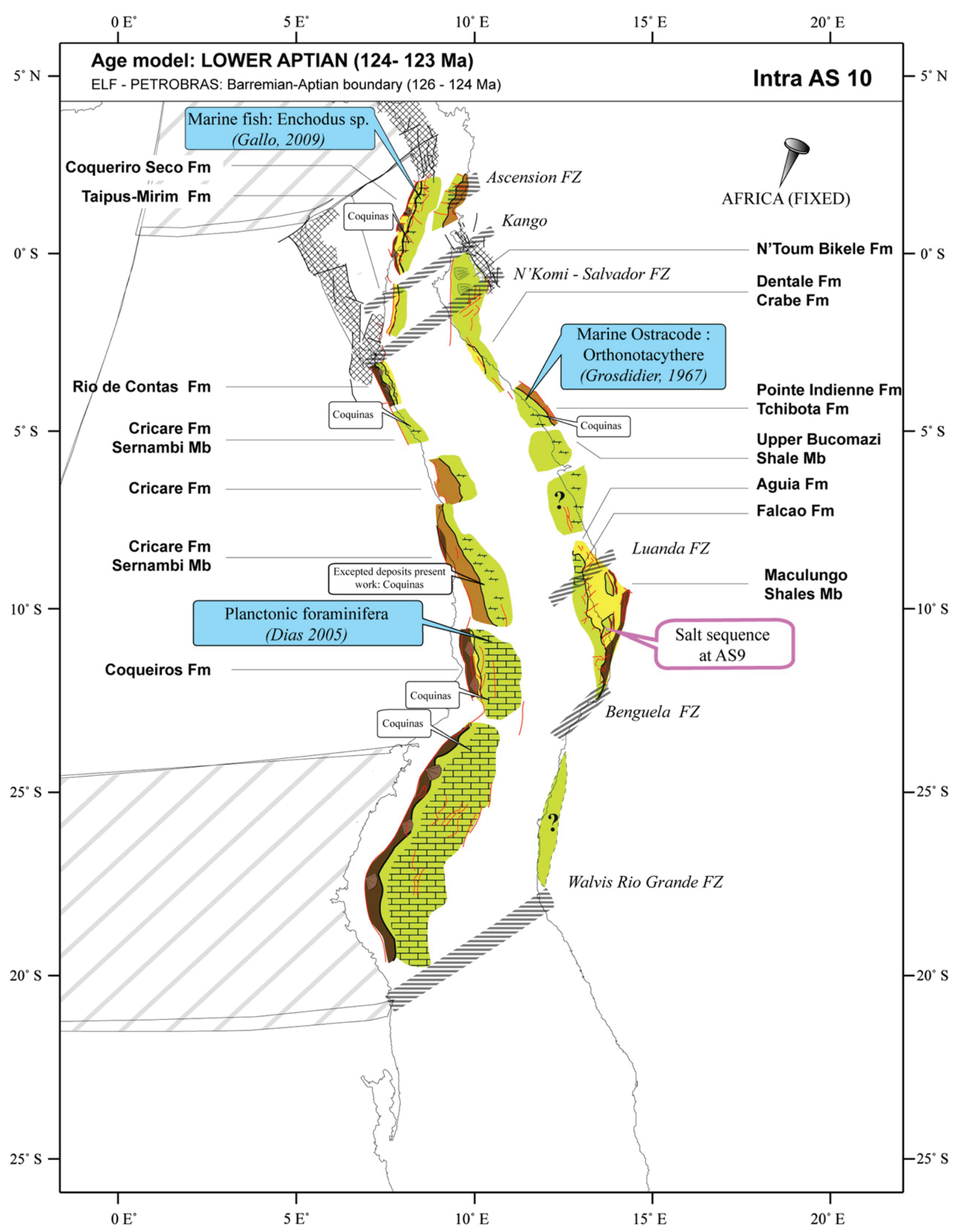

Fig. 11. Paleogeographic map at the Lower Aptian (ostracode biozone AS10) - 124-123 Ma.

the carnaillite and the tachyhydrite, with thicknesses of tachyhydrite of a few tens of meters to $100 \mathrm{~m}$ (Belmonte et al., 1965; de Ruiter, 1979; Meister and Aurich, 1971; Teisserenc and Villemin, 1990; Wardlaw, 1972; Wardlaw and Nicholls, 1972).

Silicilastic sediments of the Jacuipe to Pernambuco Basins recorded shallow lake conditions with upstream alluvial fans
(Alagoas to Pernambuco Basins, Campos Neto et al., 2007; Cordoba 728 et al., 2007).

\subsubsection{Deformation}

730

The entire South Atlantic central segment is a flexural basin, 731 except toward the north where normal faults are still active in the 732 


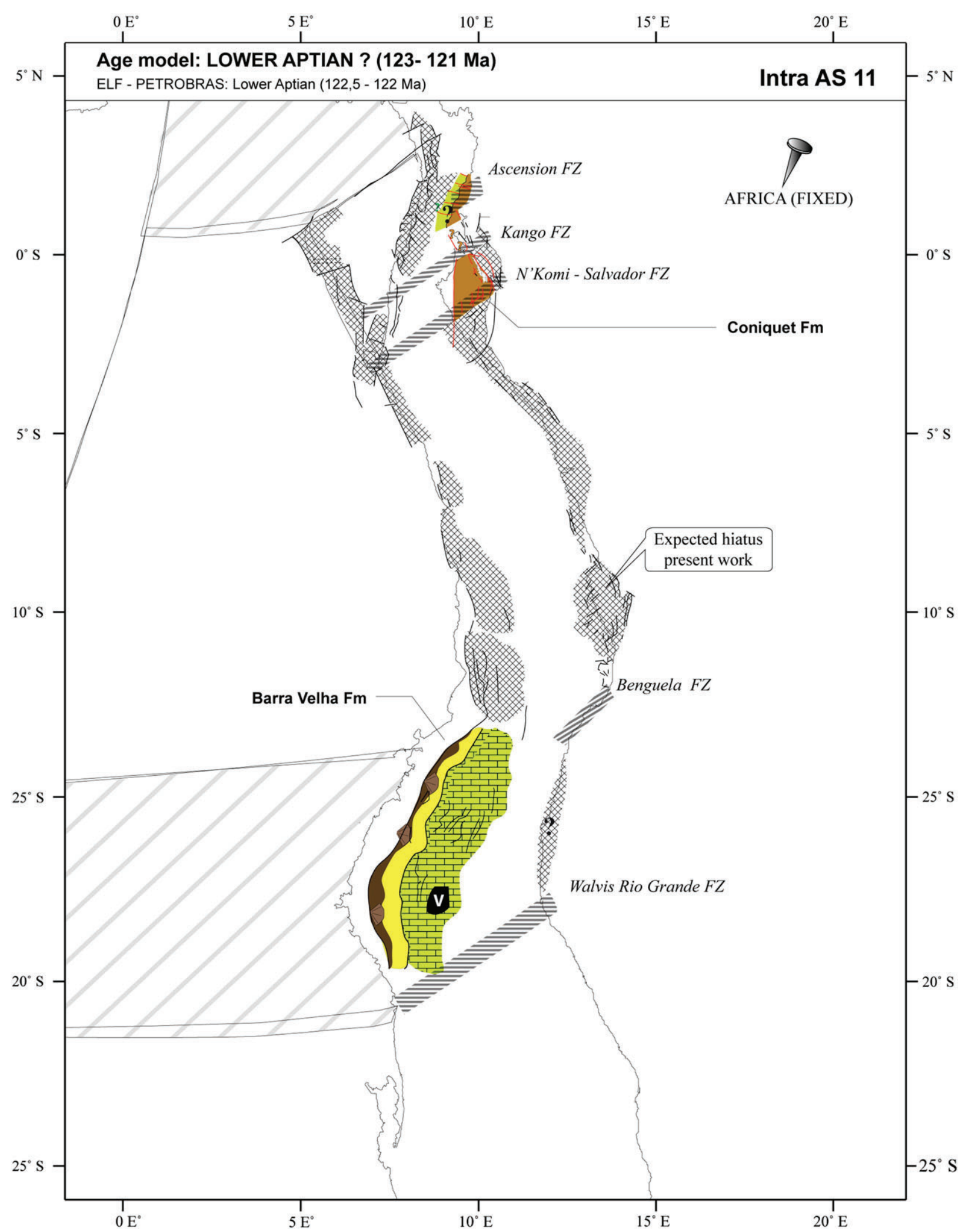

Fig. 12. Paleogeographic map at the Lower Aptian? (intra ostracode biozone AS11) - 123-121 Ma. of the salt with the oceanic crust (see Petrobras charts, Milani et al., 2007 and Fig. 5).

\section{Discussion: tectonic evolution}

Two main domains with two different tectonic and paleogeo- 738 graphic evolutions were defined along the South Atlantic central 739 


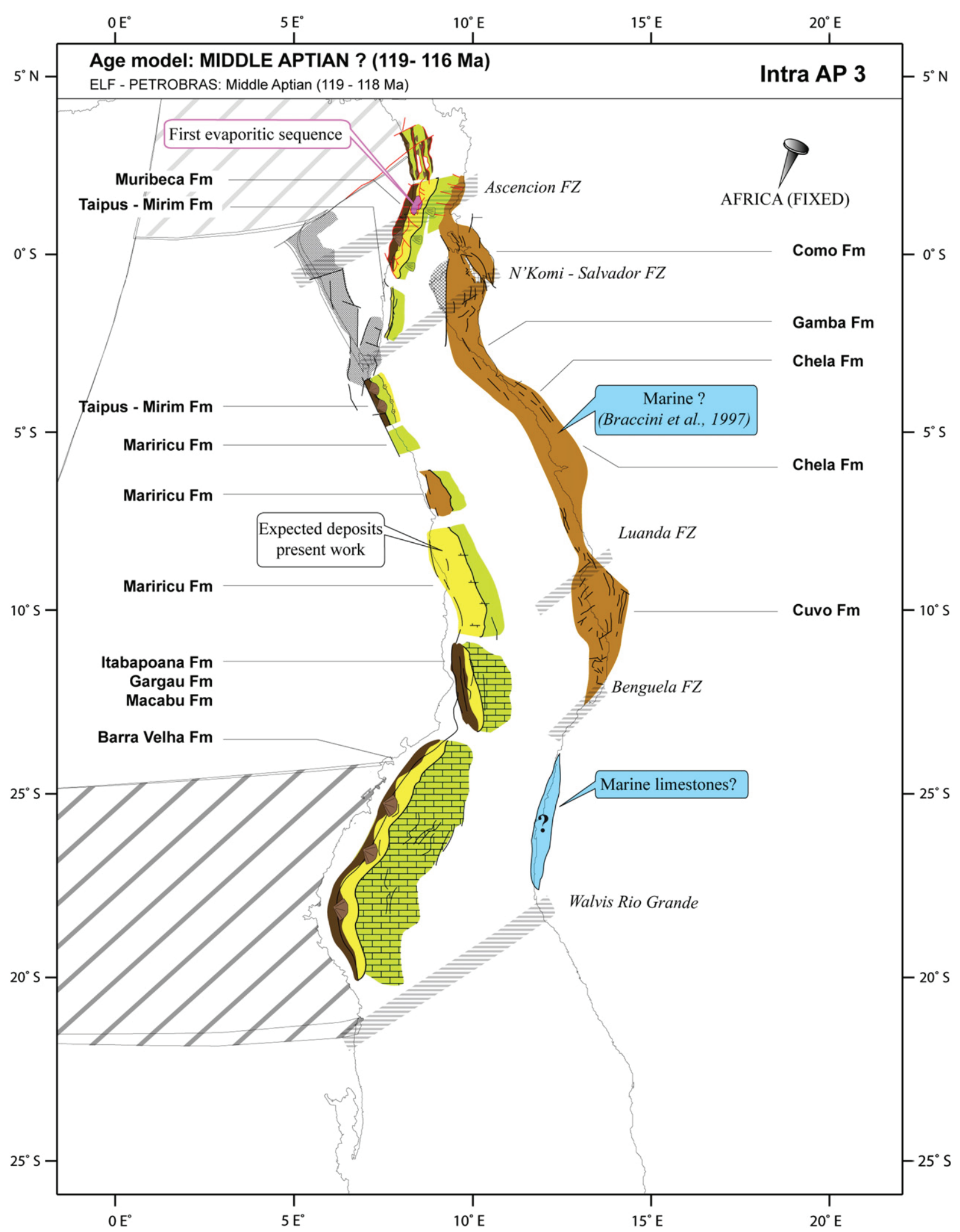

Fig. 13. Paleogeographic map at the Middle Aptian? (intra biozone AP3) - 119-116 Ma.

segment, with a changing boundary through time which propagated southward from the Abrolhos FZ (Berriasian-Valanginian boundary) to the Benguela FZ (Hauterivian-Barremian boundary). The boundary between these two domains and the status of the Campos, Espirito Santo and South Kwanza Basins are quite unclear. For Moulin et al. 745 (2012), the Santos Basin-Sao Paulo Plateau system is defined as kinematic "buffer" due to the differential extension between the 746 southern segment of the South Atlantic (south of Walvis Ridge) and 747 the northern domain of the central segment of the South Atlantic. 748 We suggest that this transitional area (Campos, Espirito Santo and 749 South Kwanza Basins) could be a sub-block boundary with highly 750 diffuse deformation. 
A

1. Intra AS 3 BERRIASIAN - VALANGINIAN BOUNDARY (141 - $139 \mathrm{Ma})$
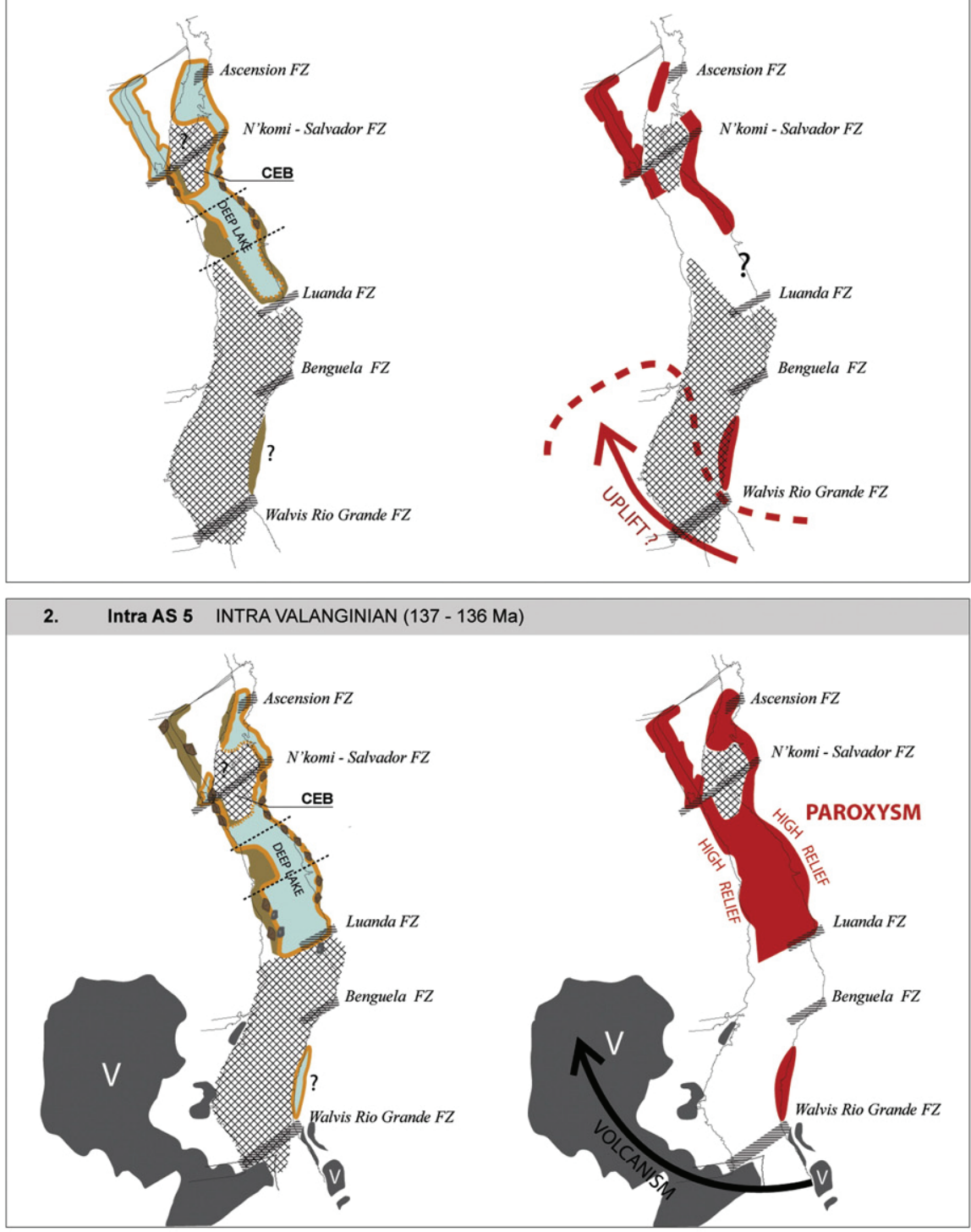

CEB Central Elevated
block
Volcanism
Oceanic crust?
Fones

BASIN TYPES
ACTIVE RIFT
FAILED RIFT
SAG

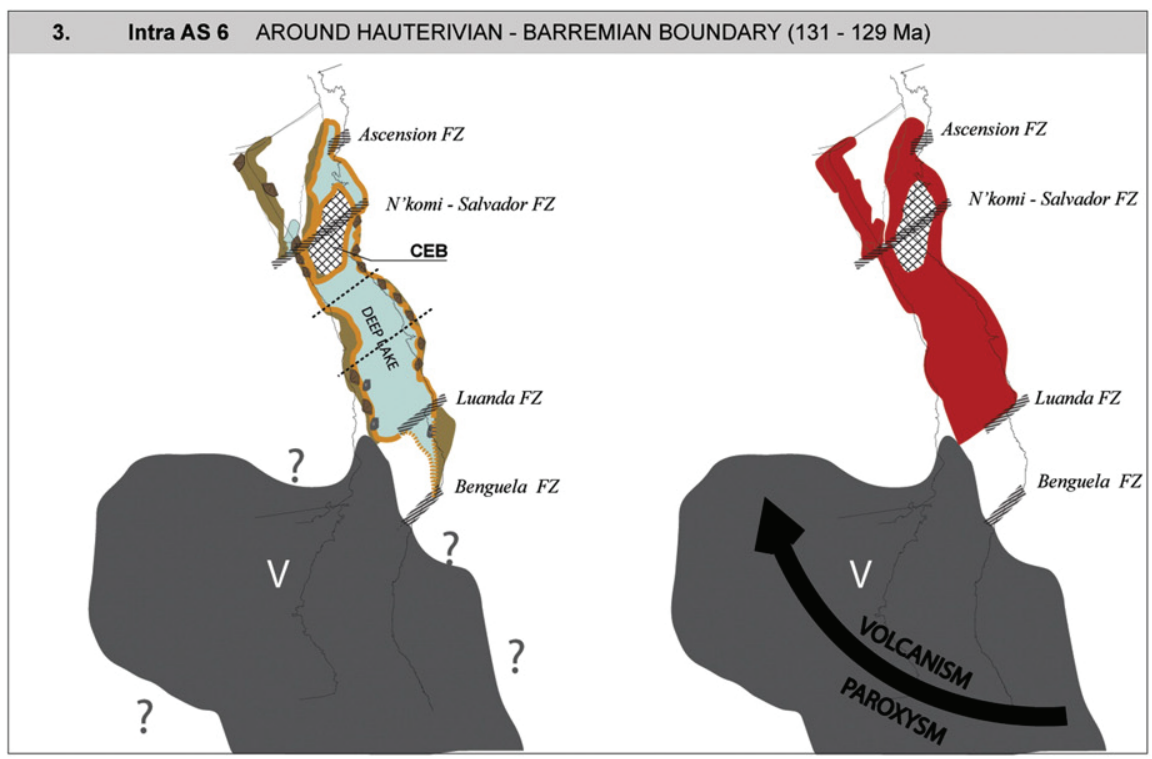

Fig. 15. Summary paleogeographic and geodynamic maps in eight stages from the Berriasian-Valanginian boundary (intra ostracode biozone AS3) to the Middle-Upper Aptian boundary (intra biozone AP4). 
B

4.

AS8 UPPER BARREMIAN (128 - $126 \mathrm{Ma})$
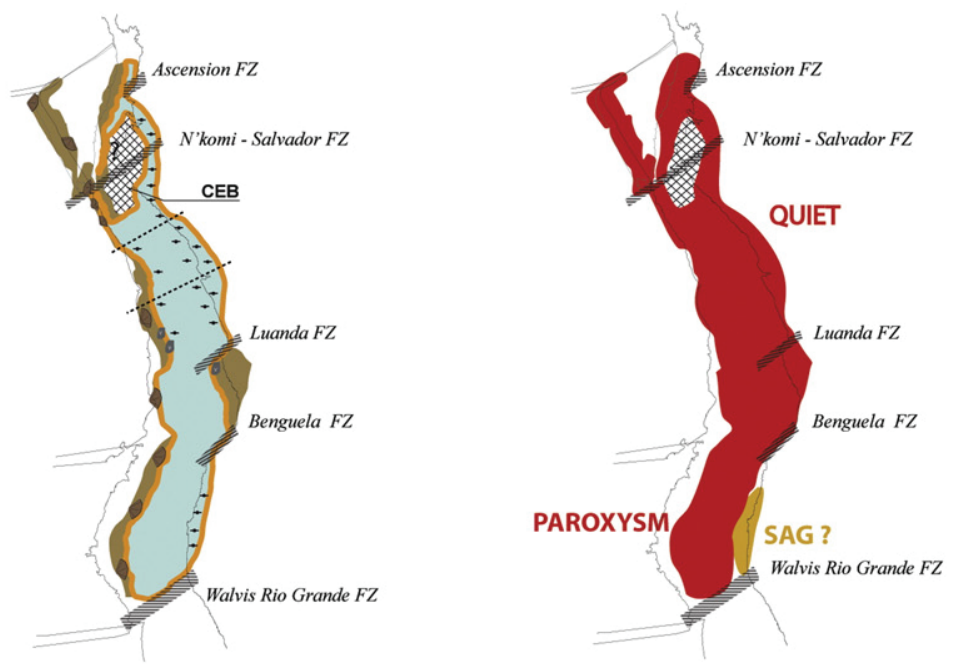

5.

AS 10 LOWER APTIAN (124 - $123 \mathrm{Ma})$

EPISODIC

MARINE

Ascension FZ

Kango FZ

N'komi - Salvador FZ

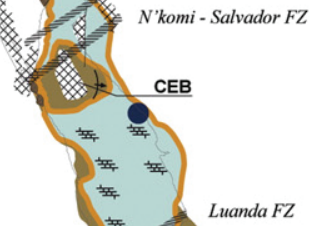

Benguela $\mathrm{FZ}$
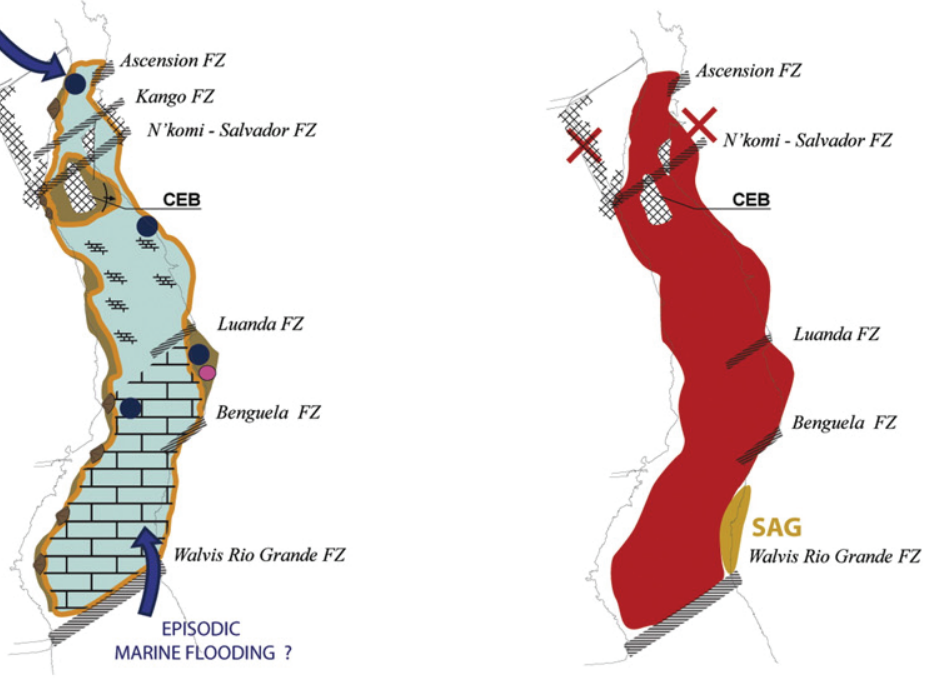

6. Infra AS 11 LOWER APTIAN ? (123-121 Ma)

Ascension FZ

Kongo FZ

N'komi - Salvador FZ

Benguela $\mathrm{FZ}$

Walvis Rio Grander FZ
Ascension FZ

Active Fault

N'komi - Salvador FZ
PALAEOGEOGRAPHY

Alluvial Fan

Alluvial plain

Lacustrine

Black shares

辛 Carbonates occurrence

- Marine occurrence

- Evaporites

Marine

Shoreline

Lacune/High

CEB Central Elevated block

Volcanism

Oceanic crust?

Fracture

Zones

BASIN TYPES

ACTIVE RIFT

FAILED RIFT

$S A G$

Fig. 15 (continued). 


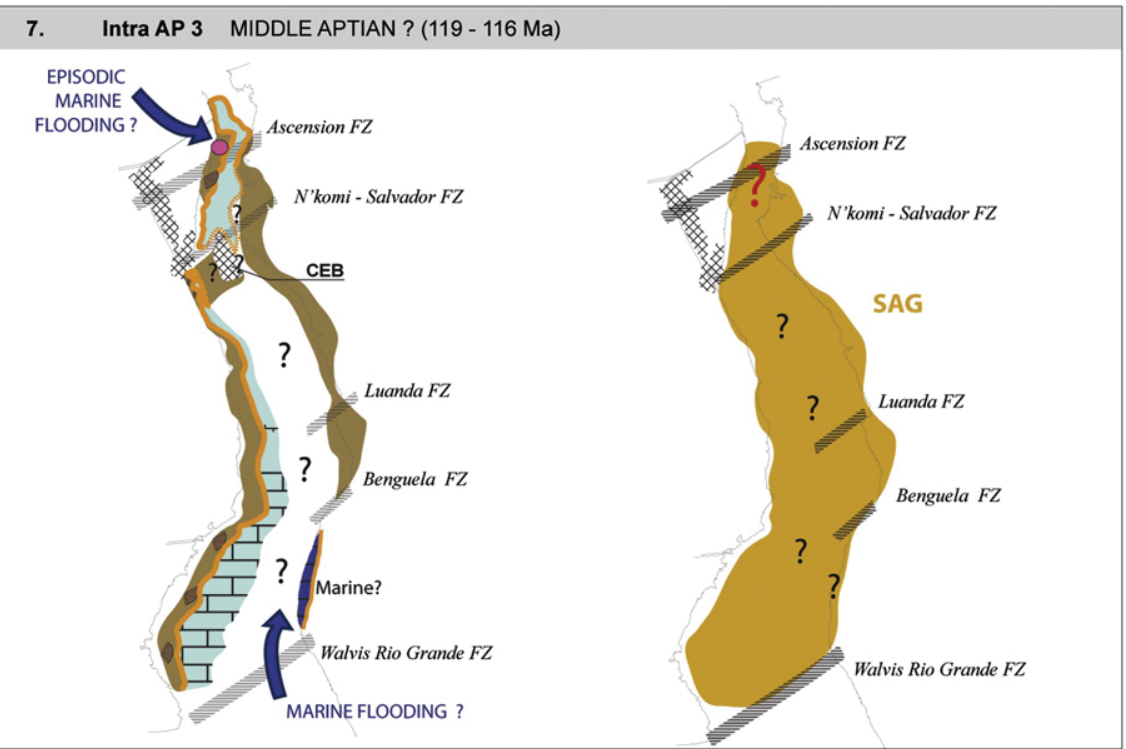

\section{PALAEOGEOGRAPHY}

- Alluvial Fan

Alluvial plain

Lacustrine

- Black shales

푬 Carbonates occurrence

- Marine occurrence

Evaporites

Marine

- Shoreline

Lacune/High

\section{CEB Central Elevated} block

8. Intra AP4 MIDDLE - UPPER APTIAN BOUNDARY (116 - $114 \mathrm{Ma})$

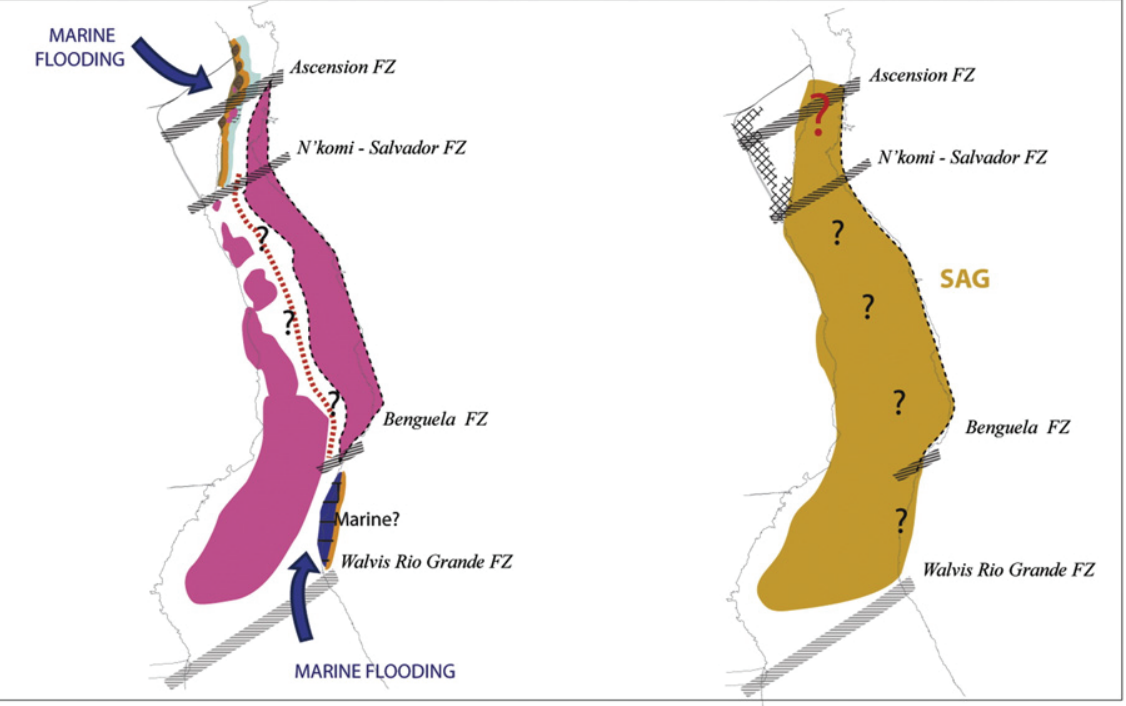

Fig. 15 (continued). during biozones AS3 and part of AS4, i.e. during the end of the Berriasian and lowermost Valanginian (141-139 Ma). In the southern domain, south of the Benguela FZ, the lithosphere extension started at least after ostracode biozone 005 (=AS7), i.e. during the Early Barremian (130-128 Ma), but an extension contemporaneous of the basaltic floods of the Cabuinas and Camboriu Formations cannot be excluded (see discussion above). This means that the lithosphere extension of the central segment of the South Atlantic Ocean migrated southward from the Gabon and NE Brazil to southern Angola and southern Brazil (Santos Basin).

The second characteristic feature is the hiatus of sedimentation during the Lower Aptian in the northern domain. As discussed above several models have been proposed for the evolution of the South Atlantic rift: the most recent ones (Aslanian et al., 2009; Huismans and Beaumont, 2008, 2011; Unternehr et al., 2010) suggest an exhumation of the lower crust/upper mantle prior to the sag phase. This could correspond to this major hiatus of possible Lower Aptian age. The relative diachronism of this hiatus along the northern domain (see above) reflects a process of variable duration through space, which is a function of the nature of the lithosphere (thickness, 781 rheology, etc.).

The sag phase corresponds to a thick wedge (Marton et al., 2000; 783 Lentini et al., 2010) of sediments, unconformably overlapping the 784 underlying sediments. Lentini's isopachs map shows a strong asym- 785 metry between our northern and southern domain, with a mainly 786 African sag in the north and a South American sag in the south and 787 a transition between these two domains where sags occurred on 788 both sides (Espirito Santo and Kwanza Basins). In spite of the poor 789 biostratigraphic resolution of the ostracode biozones and the uncer- 790 tainties in the equivalence of pollen and ostracode biozones, the sag 791 basin in the north could be older on the African side than on the 792 Brazilian side.

A characteristic feature of the northern domain is the occurrence 794 of the Central Elevated Block (CEB), north and south of the N'Komi 795 FZ. The size of this block decreases through time: at its maximum 796 size (base Valanginian), it extends from the Jequitinhonha Basin 797 southward to the Jacuipe-North Gabon Basin. The meaning of this 798 block is not quite clear: it records a splitting into two or three 799 
863 boundary (evaporites in the Kwanza Basin) and during the Early 864 Aptian (see below).

Two markers record the occurrence of rift shoulders: (1) alluvial fans associated with active normal faults and (2) the nature of the sediments and solutes coming from inland and preserved in the rift.

In the northern domain, alluvial fans are active on both sides from the Upper Berriasian (AS3, Fig. 7) to the base Barremian (AS7). The maximum growth of the alluvial fans and the maximum rate of sediment supply occur during the Valanginian (AS5) with the feeding of all the sandy turbiditic systems. After the Early Barremian, alluvial fans are mainly limited on the Brazilian side (Espirito Santo, Camamu-Almada, Reconcavo-Tucano-Jatoba, Jacuipe, and SergipeAlagoas Basins). This suggests a maximum relief on the rift flank during the Valanginian, and then a decrease with a high asymmetry during Upper Barremian times. This evolution is in agreement with (1) the few data available on the displacement along the normal fault that seems to be at its maximum in the middle part of the rift phase (Fig. 6) and decreases until the end of its activity and (2) the geochemical data (Harris, 2000; Harris et al., 2004) which suggest, on the African side, a decrease of the upstream relief at the time of deposition of the organic-rich shales ("Marnes noires" - here dated as Upper Barremian).

In the southern domain, alluvial fans are active, on the Brazilian side, from the middle part of the Barremian (AS7) to the base of the salt, i.e. during the rift and the sag phase. This suggests perennial relief in the hinterland of the Santos and Campos Basins, even during the sag phase. No reliable data are available on the African side.

\subsection{Marine floodings}

Marine floodings were identified, based on marine faunas (ostracodes, fish, foraminifers and ammonites) and geochemical characteristics of the sediments or evaporites.

The oldest evidence is not older than base Aptian. Davison and Bate (2004) cites a Late Barremian ostracode (Orthonotacythere mvili) in the Congo rift from Grosdidier (1967). But in the original publication, this ostracode is located in the "Wealdian of the Congo coastal basin, upper part" with no further details of its stratigraphic location and age. The first clear evidences of marine faunas are during the Early Aptian, with the occurrence of (1) marine ostracodes (Orthonotacythere) in the Kwanza Basin (Bate, 1999 in Davison and Bate, 2004), (2) benthic and planktonic foraminifers in the Campos Basin (Lagoa Feia Fm, Coqueiros Mbr, biozone AS10, Silva-Telles Jr., 1996 in Dias, 2005), (3) marine dinoflagellates (Subtilisphaera) in the Almada Basin (Lower Alagoas=base Taipus Mirim Fm/Itacaré Mbr, Lana and Pedrao, 2000) (4) fish (Enchodus sp.) in the Sergipe Basin (Morro do Chaves Fm, biozone AS10, Gallo, 2009) and (5) ammonites (Bengston et al., 2007). These marine influences are supported by the occurrence of salts that are older (Barremian-Aptian boundary) in the Kwanza Basin (Maculungo Fm, Middle Salt Mbr, biozone AS9, Bate, 1999) and younger in the Alagoas Basins (Coqueiro Seco Fm, biozone P230 and Maceio Fm, biozone P260, Campos Neto et al., 2007; Feijo, 1994). Hydrogen and carbon isotope geochemistry of the organic matter of the Maculungo Fm (Upper Mbr, biozone AS10, Pedentchouk et al., 2008 and stratigraphy in Pedentchouk et al., 2004) also suggest marine influences at the time of deposition. Surprisingly, true marine influences are not as obvious for the sag phase of the basin. Except for the evaporites of the Maceio Fm in the Alagoas Basin, the other place where marine influences were expected is the Cabinda Basin (Chela Fm, Biozone AP3). Braccini et al. (1997) did not mention any specific fossils, but only "probable marine deposits". In the stratigraphic synthesis of the Brazilian basins (Milani et al., 2007), a marine (e.g. Sergipe-Alagoas Basin, Campos Neto et al., 2007) or stressedtransitional marine (e.g. Santos basin, Moreira et al., 2007 or Almada Basin, Gontijo et al., 2007) is evoked for this time interval, but the arguments are not published. Such a marine flooding should be coeval with abundant, diversified marine faunas, never published on the 927 African side or on the onshore outcrops of this period in Brazil. 928

Four main periods of flooding can be expected: at the Barremian- 929 Aptian boundary (AS9, toward the South), during the Early Aptian 930 (AS10, more widespread), during the Middle(?) Aptian (limited to 931 the north) and around the Middle-Late Aptian boundary (top AS12) 932 with the widespread deposition of the evaporites.

The second point is the nature of this marine flooding which is 934 sharp and brief in a lacustrine environment or long-lasting marine 935 environment. (1) Marine evidence is scarce and the very great major- 936 ity of the described faunas (ostracodes, fish) are clearly continental 937 ones. (2) The precise sedimentologic and stratigraphic setting of 938 the marine faunas is not really described. Nevertheless, fish from 939 the Sergipe-Alagoas Basin (Morro do Chaves Fm, biozone AS10, 940 Gallo, 2009) indicate "lacustrine environments with some marine 941 influences".

The third point is the question of the origin of the marine trans- 943 gression, from the south - South Atlantic flooding above Walvis 944 Ridge, or from the north - the Tethys (Central Atlantic). Using the ma- 945 rine dinoflagellates, and mainly the Subtilisphaera ecozone, Arai 946 (2009) shows a Tethyan origin of these microfossils common in 947 Venezuela, Senegal and in northern Brazil and suggests the occurrence 948 of a seaway crossing through the Sao Luis, Parnaiba, Araripe and 949 Almada Basins and then the central segment of the South Atlantic. 950

\section{Conclusion}

Our objective was to establish the timing of the sedimentary and 952 tectonic evolution of the Early Cretaceous rift of the central segment of 953 the South Atlantic Ocean by drawing paleogeographic and geodynamic 954 maps.

1. Eight paleogeographic and deformation maps were drawn from 956 the Berriasian to the Middle-Late Aptian, based on a biostratigraphic 957 (ostracodes and pollen) chart recalibrated on absolute ages 958 (chemostratigraphy, interstratified volcanics, Re-Os dating of 959 the organic matter). Two charts were drawn: a lithostratigraphic 960 and a deformation chart.

2. The central segment of the South Atlantic is composed of two 962 domains that have a different history in term of deformation and 963 paleogeography. The southern domain includes the Namibe, 964 Santos and Campos Basins. The northern domain extends from 965 the Espirito Santo and North Kwanza Basins, in the south, to the 966 Sergipe-Alagoas and North Gabon Basins to the north.

3. We confirmed a two phase evolution of the pre-drift ("rifting") 968 times, with a rift phase characterized by tilted blocks and growth 969 strata in the inner continental crust followed by a flexural sag basin. 970

4. Extension started in the northern domain during the Late Berriasian 971 (Congo-Camamu Basin to the Sergipe-Alagoas-North Gabon Basins) 972 and migrated southward. At that time, the southern domain was not 973 a subsiding domain. This is the time of the emplacement of the 974 Parana-Etendeka Trapp (Late Hauterivian-Early Barremian). 975 Extension started in this southern domain during the Early 976 Barremian. The rift phase is shorter in the south (5-6 Ma, Barremian 977 to base Aptian) than in the north (19 to $20 \mathrm{Myr}$, Upper Berriasian to 978 base Aptian).

5. From the Late Berriasian to base Aptian, the northern domain evolves 980 from a deep lake with lateral highs to a shallower organic-rich one 981 with no more highs. The lake migrates southward in two steps, 982 until the Valanginian at the border between the northern and 983 southern domains, until the Early Barremian, north of Walvis Ridge. 984

6. The sag phase is of Middle to Late Aptian age. In the southern 985 domain, the transition between the rift and the sag phases is 986 continuous. In the northern domain, this transition corresponds 987 to a hiatus of Early to Middle Aptian age. 


\section{Uncited references}

Dias et al., 1994

Pedreao and Lana, 2000

Uesugui, 1987

\section{Acknowledgments}

This study has been supported by the ANR (French National research Agency) in the frame of the TopoAfrica project and by the IFP Energies nouvelles in the frame of the project "Climate and sedimentation - South Atlantic opening”. Dr. S. Mullin post edited the English style.

\section{References}

Abreu, V.d.S., 1998. Geologic evolution of conjugate volcanic passive margins; Pelotas Basin (Brazil) and offshore Namibia (Africa); implication for global sea level changes. Ph.D. Thesis, Rice University, Houston, Texas. 355 pp.

Anderson, J.E., Cartwright, J., Drysdall, S.J., Vivian, N., 2000. Controls on turbidite sand deposition during gravity-driven extension of a passive margin; examples from Miocene sediments in Block 4, Angola. Marine and Petroleum Geology 17 1165-1203.

Arai, M., 2009. Paleogeografia do Atlantico Sul no Aptiano: um novo modelo a partir de dados micropaleontologicos recentes. Boletim de Geociencias da Petrobras 17, 331-351.

Arai, M., Hashimoto, A.T., Uesugui, N., 1989. Significado cronoestratigrafico da associacao microfloristica do Cretaceo Inferior do Brasil. Boletim de Geociencias da Petrobras 3, 87-103.

Aslanian, D., Moulin, M., 2010. Comment on "A new scheme for the opening of the South Atlantic Ocean and the dissection of an Aptian salt basin" by Trond H Torsvik, Sonia Rousse, Cinthia Labails and Mark A. Smethurst. Geophysical Journal International 183, 20-28.

Aslanian, D., Moulin, M., 2012. Paleogeographic consequences of conservational models in the South Atlantic Ocean. In: Mohriak, W.U., Danforth, A., Post, P.J., Brown, D.E., Tari, G.C., Nemcok, M., Sinha, S.T. (Eds.), Conjugate Divergent Margins: Geological Society, London, Special Publications, 369.

Aslanian, D., Moulin, M., Olivet, J.L., Unternehr, P., Matias, L., Bache, F., Rabineau, M., Nouzé, H., Klingelheofer, F., Contrucci, I., Labails, C., 2009. Brazilian and African passive margins of the Central Segment of the South Atlantic Ocean: kinematic constraints. Tectonophysics 468, 98-112.

Bate, R.H., 1999. Non-marine ostracod assemblages of the pre-salt rift basins of West Africa and their role in sequence stratigraphy. In: Cameron, N.R., Bate, R.H., Clure, V.S. (Eds.), The Oil and Gas Habitats of the South Atlantic: Geological Society, London, Special Publications, 153, pp. 283-292.

Bate, R.H., Cameron, N.R., Brandao, M.G.P., 2001. Lower Cretaceous (pre-Salt) lithostratigraphy of the Kwanza Basin, Angola. Newsletters on Stratigraphy 38, 117-127.

Belmonte, Y., Hirtz, P., Wenger, R., 1965. The salt basins of the Gabon and the Congo (Brazzaville); a tentative palaeogeographic interpretation. In: Ion, D.C. (Ed.), Salt Basins around Africa. The institute of Petroleum, London, pp. 55-74.

Bengston, P., Koutsoukos, E.A., Kakabadze, M.V., Zucon, M.H., 2007. Ammonite and foraminiferal biogeography and the opening of the Equatorial Atlantic Gateway. First International Palaeobiogeography Symposium, Paris, p. 12. Abstracts.

Blaich, O.A., Faleide, J.I., Tsikalas, F., Lilletveit, R., Chiossi, D., Brockbank, P., Cobbold, P., 2010. Structural architecture and nature of the continent-ocean transitional domain at the Camamu and Almada Basins (NE Brazil) within a conjugate margin setting. In: Vining, B.A., Pickering, S.C. (Eds.), Petroleum Geology: From Mature Basins to New Frontiers - Proceedings of the 7th Petroleum Geology Conference. Geological Society, London, pp. 867-883.

Blaich, O.A., Faleide, J.I., Tsikalas, F., 2011. Crustal breakup and continent-ocean transition at South Atlantic conjugate margins. Journal of Geophysical Research 116, B01402 http://dx.doi.org/10.1029/2010JB007686.

Borba, C., Paim, P.S.G., Garcia, A.J.V., 2011. Estratigrafia dos depósitos iniciais do rifte no Campo de Furado, região de São Miguel dos Campos, Bacia de Sergipe-Alagoas. Revista Brasileira de Geociencias 41, 18-36.

Braccini, E., Denison, C.N., Scheevel, J.R., Jeronimo, P., Orsolini, P., Barletta, V., 1997. A revised chrono-lithostratigraphic framework for the pre-Salt (Lower Cretaceous) in Cabinda, Angola. Bulletin des Centres de Recherches Exploration-Production Elf-Aquitaine 21, 125-151.

Bracken, B.R., 1994. Syn-rift lacustrine beach and deltaic sandstone reservoirs - pre-salt 1061 (Lower Cretaceous) of Cabinda, Angola, West Africa. In: Lomando, A.J., Schreiber, B.C., 1062 Harris, P.M. (Eds.), Lacustrine reservoirs and depositional systems: Society for 1063 Economic Paleontologists and Mineralogists, Core, Workshop, 19, pp. 173-200. 1064 Bruhn, C.H.L., 1999. Reservoir architecture of deep-lacustrine sandstones from 1065 the Early Cretaceous Recôncavo Basin, Brazil. American Association of Petroleum 1066 Geologists Bulletin 83, 1502-1525.

Brun, J.P., 1999. Narrow rifts versus wide rifts; inferences for the mechanics of rifting 1068 from laboratory experiments. Philosophical Transactions of the Royal Society. 1069 Series A - Mathematical. Physical and Engineering Sciences 357, 695-712.

Brun, J.P., Beslier, M.O., 1996. Mantle exhumation at passive margins. Earth and Planetary 1071 Science Letters 142, 161-173.

de eventos no rifte Sul-Atlântico. Boletim ze Geosciências da Petrobras 12, 203-229. 1074

Burke, K., Dewey, J.F., 1978. Two plates in Africa during the Cretaceous? Nature 249, 1075 313-316. 1076

Burwood, R., Leplat, P., Mycke, B., Paulet, J., 1992. Rifted margin source rock deposition: 1077 a carbon isotope and biomarker study of a West African Lower Cretaceous 'lacus- 1078 trine' section. Organic Geochemistry 19, 41-52. 1079

Caixeta, J.M., Milhomem, P.d.S., Witzke, R.E., Dupuy, I.S.S., Gontijo, G.A., 2007. Bacia de 1080 Camamu. Boletim de Geociencias da Petrobras 15, 455-461. 1081

Campos Neto, O.P.d.A., Lima, W.S., Gomes Cruz, F.E., 2007. Bacia de Sergipe-Alagoas. 1082 Boletim de Geociencias da Petrobras 15, 405-415. 1083

Carvalho, G.S., 1961. Geologia do deserto de Moçâmedes (Angola). Memorias da Junta 1084 de Investigaçoes do Ultramar, 26. 227 pp.

Carvalho, M.D., Praca, U.M., da Silva-Telles Jr., A.C., Jahnert, R.J., Dias, J.L., 2000a. 1086 Bioclastic carbonate lacustrine facies models in the Campos Basin (Lower 1087 Cretaceous), Brazil. In: Gierlowski-Kordesch, E.H., Kelts, K.R. (Eds.), Lake Basins 1088 Through Space and Time: American Association of Petroleum Geology, Studies in 1089 Geology, 46, pp. 245-256.

Grvalho, M.D., Praca, U.M., da Silva Telles Jr., A.C., Jahnert, R.J., Dias, J.L., 2000b. 1091 Bioclastic carbonate lacustrine facies models in the Campos Basin (Lower Creta- 1092 eeous), Brazil. In: Gierlowski Kordesch, E.H., Kelts, K.R. (Eds.), Lake basins through 1093 space and time: American Association of Petroleum Geology Studies in Geology, 1094 46, pp. 245-256.

Chiossi, D.S.N., 2005. Sequencias deposicionais de $3^{\mathrm{a}}$ ordem em riftes continentais: um 1096 modelo de tratos de sistemas para grabens assimetricos aplicado ao Cretaceo Infe- 1097 rior da bacia de Sergipe-Alagoas. Boletim de Geociencias da Petrobras 13, 181-203. 1098

Contrucci, I., Matias, L., Moulin, M., Geli, L., Klingelhofer, F., Nouze, H., Aslanian, D., Olivet, 1099 J.-L., Rehault, J.-P., Sibuet, J.-C., 2004. Deep structure of the West African continental 1100 margin (Congo, Zaire, Angola), between $5^{\circ} \mathrm{S}$ and $8^{\circ} \mathrm{S}$, from reflection/refraction seis- 1101 mics and gravity data. Geophysical Journal International 158, 529-553.

Cordoba, V.C., Sa, E.F.J., Sousa, D.d.C., Antunes, A.F., 2007. Bacia de Pernambuco-Paraiba. 1103 Boletim de Geociencias da Petrobras 15, 391-403.

Costa, IP , Milhomem, P.d.S.,Bueno, G.V., Silva, HS.R. Ko Tucano Sul e Central. Boletim de Geociencias da Petrobras 15, 433-443. 1106

Coterill, K., Tari, G.C., Molnar, J., Ashton, P.R., 2002. Comparison of depositional 1107 sequences and tectonic styles among the West African deepwater frontiers of 1108 western Ivory Coast, southern Equatorial Guinea, and northern Namibia. Leading 1109 Edge 21, 1103-1111.

Cox, K.G., 1989. The role of mantle plumes in the development of continental drainage 1111 patterns. Nature 342, 873-876.

Creaser, R.A., Kendall, B., Morelli, R.M., 2008. Advances in crustal geochronology of 1113 shales and sulfide minerals using ${ }^{187}$ Re- $-{ }^{187}$ Os. Geochimica et Cosmochimica Acta 1114 72, A188-A188.

Cupertino, J.A., Bueno, G.V., 2005. Arquitetura das sequencias estratigraficas 1116 desenvolvidas na fase de lago profundo no rifte do Reconcavo. Boletim de 1117 Geociencias da Petrobras 13, 245-267.

Curie, D., 1984. Ouverture de l'Atlantique sud et discontinuités intra-plaque: une nouvelle 1119 analyse. Thèse de $3^{\text {ème }}$ cycle. Université de Bretagne Occidentale, Brest. 192 pp. 1120

Davison, I., 1999. Tectonics and hydrocarbon distribution along the Brazilian South Atlan- 1121 tic margin. In: Cameron, N.R., Clure, V.S. (Eds.), The Oil and Gas Habitats of the South 1122 Atlantic: Geological Society of London, Special Publications, 153, pp. 133-151. 1123

Davison, I., 2007. Geology and tectonics of the South Atlantic Brazilian salt basins. In: 1124 Ries, A.C., Butler, R.W.H., Graham, R.H. (Eds.), Deformation of the Continental 1125 Crust: The Legacy of Mike Coward: Geological Society, London, Special Publica- 1126 tions, 272, pp. 345-359.

Davison, I., Bate, R.H., 2004. Early opening of the South Atlantic: Berriasian rifting to 1128 Aptian salt deposition. PESGB/HGS 3rd International Joint Meeting - Africa: the 1129 Continent of Challenge and Opportunity, London.

de Ruiter, P.A.C., 1979. The Gabon and Congo basins salt deposits. Economic Geology 1131 74, 419-431.

Deckart, K., Feraud, G., Marques, L.S., Bertrand, H., 1998. New time constraints on dyke 1133 swarms related to the Parana-Etendeka magmatic province, and subsequent South 1134 Atlantic opening, southeastern Brazil. Journal of Volcanology and Geothermal 1135 Research 80, 67-83.

Dias, J.L., 2005. Tectônica, estratigrafia e sedimentação no andar Aptiano da margem 1137 leste Brasileira. Boletim de Geociencias da Petrobras 13, 7-25.

Dias, J.L., da Oliveira, J.Q., Vieira, J.C., 1988. Sedimentological and stratigraphic analysis 1139 of the Lagoa Feia Formation, rift phase of Campos Basin, offshore Brazil. Revista 1140 Brasileira de Geociencias 18, 252-260.

Dias, J.L., Sad, A.R.E., Fontana, R.L., Feijo, F.J., 1994. Bacia de Pelotas. Boletim de 1142 Geociencias da Petrobras 8,235245

Doyle, J.A., Biens, P., Doerenkamp, A., Jardiné, S., 1977. Angiosperm pollen from the Pre- 1144 Albian Lower Cretaceous of equatorial Africa. Bulletin des Centres de Recherche et 1145 d'Exploration-Production Elf-Aquitaine 1, 451-473. 
Koutsoukos, E.A.M., Bengston, P., 1993. Towards an integrated biostratigraphy of the 1233 upper Aptian-Maastrichtian of the Sergipe Basin, Brazil. Documents des 1234 Laboratoires de Geologie, Lyon 125, 241-262. Recherche et d'Exploration-Production Elf-Aquitaine 6, 39-117.

Duval, B.C., Cramez, C., Jackson, M.P.A., 1992. Raft tectonics in the Kwanza Basin, Angola. Marine and Petroleum Geology 9, 389-404.

Dyer, M.J., 2008. South Atlantic - Brazil's Tupi Discovery - Insights \& Implications for Opportunities. North America Prospect Expo (NAPE), Houston.

Eagles, G., 2007. New angles on South Atlantic opening. Geophysical Journal International $168,353-361$.

Evans, R., 1978. Origin and significance of evaporites in basins around Atlantic margin. American Association of Petroleum Geology Bulletin 62, 223-234.

Feijo, F.J., 1994. Bacias de Sergipe e Alagoas. Boletim de Geociencias da Petrobras 8, 149-161. igueiredo, A.M.F., Braga, J.A.E., Zabalaga, J.C., Oliveira, J.J., Aguiar, G.A., Silva, O.B., Mato, L.F., Daniel, L.M.F., Magnavita, L.P., Bruhn, C.H.L., 1994. Reconcavo Basin, Brazil; a prolific intracontinental rift basin. In: Landon, S.M. (Ed.), Interior Rift Basins: American Association of Petroleum Geology Memoir, 59, pp. 157-203.

Fonck, J.M., Cramez, C., Jackson, M.P.A., 1998. Role of subaerial volcanic rocks and major unconformities in the creation of South Atlantic margins. American Association of Petroleum Geology Bulletin 82, 1914-1915.

França, R.L., Del Rey, A.C., Tagliari, C.V., Brandao, J.R., Fontanelli, P.d.R., 2007. Bacia do Espirito Santo. Boletim de Geociencias da Petrobras 15, 501-509.

Gallo, V., 2009. A paleoictiofauna marinha das bacias marginais brasileiras. Congresso Brasileiro de Paleontologia, 21. Belèm, Livro de Resumos, p. 266.

Gilchrist, A.R., Summertield, M.A., 1994. Tectonic models of passive margin evolution and their implications for theories of long-term landscape development. In: Kirkby, M.J. (Ed.), Process Models and Theoretical Geomorphology. Wiley, Chichester, pp. 55-84.

Gonçalves, F.T.T., 2001. Controles limnologicos sobre a formaçao de rochas geradoras de petroleo lacustres: o exemplo da Bacia de Camamu, nordeste do Brasil. Geociências 20, 5-23.

Gontijo, G.A., Milhomem, P.d.S., Caixeta, J.M., Dupuy, I.S.S., Menezes, P.E.L., 2007. Bacia de Almada. Boletim de Geociencias da Petrobras 15, 463-473.

Graddi, J.S.V., Campos Neto, O.P.d.A., Caixeta, J.M., 2007. Bacia de Jacuipe. Boletim de Geociências da Petrobras 15, 417-421.

Grosdidier, E., 1967. Quelques ostracodes nouveaux de la serie ante-salifere ('wealdienne') des bassins cotiers du Gabon et du Congo. Revue de Micropaleontologie 10, 107-116.

Grosdidier, E., Braccini, E., Dupont, G., Moron, J.M., 1996. Biozonation du Crétacé Inférieur non marin des bassins du Gabon et du Congo. In: Jardiné, S., de Klasz, I., Debenay, J.P. (Eds.), Géologie de l'Afrique et de l'Atlantique Sud : Actes des Colloques d'Angers 1994: Mémoires Elf-Aquitaine, 16, pp. 67-82.

Guardado, L.R., Gamboa, L.A.P., Lucchesi, C.F., 1990. Petroleum geology of the Campos Basin, Brazil; a model for a producing atlantic type basin. In: Edwards, J.D., Santogrossi, P.A. (Eds.), Divergent/passive margins basins: American Association of Petroleum Geologists Memoir, 48, pp. 3-79,

Guedes, E., Heilbron, M., Vasconcelos, P.M., de Morisson Valeriano, C., Horta de Almeida, J.C., Teixeira, W., Thomaz Filho, A., 2005. K/Ar and ${ }^{40} \mathrm{Ar} /{ }^{39} \mathrm{Ar}$ ages of dikes emplaced in the onshore basement of the Santos Basin, Resende area, SE Brazil; implications for the South Atlantic opening and Tertiary reactivation. Journal of South American Earth Sciences 18, 371-382.

Guiraud, R., Maurin, J.-C., 1991. Le Rifting en Afrique au Crétacé inférieur; synthèse structurale, mise en evidence de deux étapes dans la genèse des bassins, relations avec les ouvertures oceaniques péri-africaines. Bulletin de la Société Géologique de France 162, 811-823.

Guiraud, R., Maurin, J.-C., 1992. Early Cretaceous rifts of western and central Africa: an overview. Tectonophysics $213,153-168$.

arris, N.B., 2000. Evolution of the Congo rift basin, West Africa; an inorganic geochemical record in lacustrine shales. Basin Research 12, 425-445.

Harris, N.B., Sorriaux, P., Toomey, D.F., 1994. Geology of the Lower Cretaceous Viodo carbonate: a lacustrine carbonate in the South Atlantic rift. In: Lomando, A.J. Schreiber, B.C., Harris, N.B. (Eds.), Lacustrine reservoirs and depositional systems: Society for Economic Paleontology and Mineralogy (SEPM), Core workshops, 19, pp. $143-172$.

arris, N.B., Freeman, K.H., Pancost, R.D., White, T.S., Mitchell, G.D., 2004. The character and origin of lacustrine source rocks in the Lower Cretaceous synrift section, Congo Basin, West Africa. American Association of Petroleum Geology Bulletin 88, $1163-1184$

Huismans, R.S., Beaumont, C., 2008. Complex rifted continental margins explained by dynamical models of depth-dependent lithospheric extension. Geology 36, $163-166$.

Huismans, R.S., Beaumont, C., 2011. Depth-dependent extension, two-stage breakup and cratonic underplating at rifted margins. Nature 473, 74-78.

ackson, M.P.A., Cramez, C., Fonck, K.-M., 2000. Role of subaerial volcanic rocks and mantle plumes in creation of South Atlantic margins; implications for salt tectonics and source rocks. Marine and Petroleum Geology 17, 477-498.

Karner, G.D., Driscoll, N.W., 1999. Tectonic and stratigraphic development of the West African and eastern Brazilian margins; insights from quantitative basin modelling. In: Cameron, N.R., Clure, V.S. (Eds.), The Oil and Gas Habitats of the South Atlantic: Geological Society, London, Special Publications, 153, pp. 11-40.

Karner, G.D., Driscoll, N.W., McGinnis, J.P., Brumbaugh, W.D., Cameron, N.R., 1997. Tectonic significance of syn-rift sediment packages across the Gabon-Cabinda continental margin. Marine and Petroleum Geology 14, 973-1000.

Karner, G.D., Driscoll, N.W., Barker, D.H.N., 2003. Syn-rift region subsidence across the West African continental margin; the role of lower plate ductile extension. In: Arthur, T.J., MacGregor, D.S., Cameron, N.R. (Eds.), Geological Society, London, Special Publications, 207, pp. 105-129.
Kuo, L.-C., 1994. Lower Cretaceous lacustrine source rocks in northern Gabon; effect of 1236 organic facies and thermal maturity on crude oil quality. Organic Geochemistry 22, 1237 $257-273$.

Lana, C.C., Pedrao, E., 2000. Um episodio de incursao marinha no eoaptiano (eoalagoas) 1239 da bacia de Almada, BA, Brazil. Revista Universidade de Guarulhos - Geosciências 1240 $\mathrm{V}$ (nº especial), pp. 89-92.

Lavier, L.L., Manatschal, G., 2006. A mechanism to thin the continental lithosphere at 1242 magma-poor margins. Nature 440, 324-328.

Lentini, M.R., Fraser, S.I., Sumner, H.S., Davies, R.J., 2010 Geodynamics of the 1244 central Sauth Atlantic conimoste maroinc. implications for hydrocarbon potential. 1245

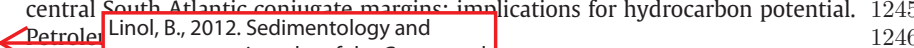

Magnavita, sequence stratigraphy of the Congo and eiros geológicos, guia de campo da 1247 Bacia the Kalahari basins of Southcentral de Geociencias da Petrobras 13, 1248 301-33 Africa and their evolutions during the 1249

Marton, L.G formation and the breakup of West -ion of the Angolan passive margin, 1250 West Gondwana. Ph.D. Thesis, Faculty of tructural styles. In: Mohriak, W., 1251 Talwan Sciences at the Nelson Mandela $\quad$ tal Margins: American Geophysical 1252 Union, Metropolitan University, Port Elisabeth, $129-149 . \quad 1253$

Matos, R.M. South Africa. 361 pp. $\quad$ stem. Tectonics 11, 766-791. 125

Matos, R.M. lian rift system; kinematic implica- 1255

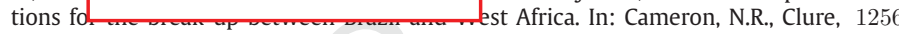
V.S. (Eds.), The Oil and Gas Habitats of the South Atlantic: Geological Society, 1257 London, Special Publications, 153, pp. 55-73.

Mbina Mounguengui, M., Guiraud, M., 2009. Neocomian to early Aptian syn-rift evolu- 1259 tion of the normal to oblique-rifted north Gabon margin (Interior and N'Komi 1260 Basins). Marine and Petroleum Geology 26, 1000-1017.

Mbina Mounguengui, M., Lang, J., Guiraud, M., 2008. Sedimentary dynamics and exten- 1262 sional structuring related to early Cretaceous rifting of Neocomian and Barremian 1263 deposits of the interior basin of Gabon. Journal of African Earth Sciences 51, 1264 239-256.

McHargue, T.R., 1990. Stratigraphic development of proto-South Atlantic rifting in 1266 Cabinda, Angola - a petroliferous lake basin. In: Katz, B.J. (Ed.), Lacustrine basin 1267 exploration. Case Studies and Modern Analogs: American Association of Petroleum 1268 Geology Memoirs, 50, pp. 307-326.

McKenzie, D. 1978. Some remarks on the development of sedimentary basins. Earth 1270 and Planetary Science Letters 40, 25-32.

Meister, E.M., Aurich, N., 1971. Geologic outline and oil fields of Sergipe Basin, Brazil. 1272 American Association of Petroleum Geologists Bulletin 55, 353 353.

Mello, M.R., Telnaes, N., Gaglianone, P.C., Chicarelli, M.I., Brassell, S.C., Maxwell, J.R., 1274 1988. Organic geochemical characterisation of depositional palaeoenvironments 1275 of source rocks and oils in Brazilian marginal basins. Organic Geochemistry 13, 1276 $31-45$.

Milani, E.J., Rangel, H.D., Bueno, G.V., Stica, J.M., Winter, W.R., Caixeta, J.M., Pessoa Neto, 1278 O.C.P., 2007. Bacias sedimentares brasileiras; cartas estratigraficas. Brazilian sedi- 1279 mentary basins; stratigraphic charts. Boletim de Geociencias da Petrobras 15, 1280 183-205.

Mohriak, W.U., Rosendahl, B.R., 2003. Transform zones in the South Atlantic rifted 1282 continental margins. In: Storti, F., Holdsworth, R.E., Salvini, F. (Eds.), Intraplate 1283 Strike-Slip Deformation Belts: Geological Society, London, Special Publications, 1284 210, pp. 211-228.

Mohriak, W.U. Lira Rabelo, J. De Matos, R.D. De Barros, M.C. 1995. Deep seismic 1286 reflection profiling of sedimentary basins offshore Brazil: geological objectives 1287 and preliminary results in the Sergipe Basin. Journal of Geodynamics 20, 515-539. 1288

Mohriak, W.U., Bassetto, M. Vieira, I.S., 1998. Crustal architecture and tectonic evolu- 1289 tion of the Sergipe-Alagoas and Jacuipe basins, offshore northeastern Brazil. 1290 Tectonophysics 288, 199-220.

Mohriak, W. Nemcok, M., Enciso, G., 2008. South Atlantic divergent margin evolution; 1292 rift-border uplift and salt tectonics in the basins of SE Brazil. In: Pankhurst, R.J., 1293 Trouw, R.A.J., Brito Neves, B.B., De Wit, M.J. (Eds.), West Gondwana: Pre-Cenozoic 1294 Correlations Across the South Atlantic Region: Geological Society, London, Special 1295 Publications, 294, pp. 365-398.

Moreira, J.L.P., Madeira, C.V., Gil, J.A., Machado, M.A.P., 2007. Bacia de Santos. Boletim 1297 de Geociencias da Petrobras 15, 531-549.

Moulin, M., Aslanian, D., Olivet, J., Contrucci, I., Matias, L., Geli, L., Klingelhoefer, F., 1299 Nouze, H., Rabineau, M., Labails, C., Rehault, J., Unternehr, P., 2005. Geological con- 1300 straints on the evolution of the Angolan margin based on reflection and refraction 1301 seismic data (ZaiAngo Project). Geophysical Journal International 162, 793-810. 1302

Moulin, M., Aslanian, D., Unternehr, P., 2010. A new starting point for the South and 1303 Equatorial Atlantic Ocean. Earth-Science Reviews 98, 1-37.

Moulin, M. Aslanian, D. Rabineau, M. Patriat, M. Matias, L, 2012. Kinematic keys of 1305 the Santos Basin. In: Mohriak, W.U., Danforth, A., Post, P.J., Brown, D.E., Tari, G.C., 1306 Nemcok, M., Sinha, S.T. (Eds.), Conjugate Divergent Margins: Geological Society, 1307 London, Special Publications, 369.

Moura, JA, 1972. Algumas especies Reconcavo/Tucano. Boletim Tecnico da Petrobras 15, 245-263.

Netto, A.S.T., Filho, J.R.W., Feijo, F.J., 1994. Bacias de Jacuipe, Camamu e Almada. Boletim 1311 de Geociencias da Petrobras 8, 173-184

Novais, L.C.C., Teixeira, L.B., Neves, M.T., Rodarte, J.B.M., Almeida, J.C.H., Valeriano, C.M., 1313 2004. Novas ocorrencias de diques de diabasio na faixa Colatina, ES; estruturas 1314 rupteis associadas e implicacoes tectonicas para as bacias de Campos e do Espirito 1315 Santo. Boletim de Geociencias da Petrobras 12, 191-194. Jurassic to present. Tectonophysics 191, 27-53. 
Scotchman, I., Chiossi, D., 2009. Kilometre-scale uplift of the Early Cretaceous rift 1359 section, Camamu Basin, offshore north-east Brazil. Search and Discovery article 1360

Silva, O.B., Caixeta, J.M., Milhomem, P.d.S., Kosin, M.D., 2007. Bacia do Reconcavo. 1362 Boletim de Geociencias da Petrobras 15, 423-431. 1363

Smith, R.D.A., 1995. Reservoir architecture of syn-rift lacustrine turbidite systems, Early 1364 Cretaceous, offshore South Gabon. In: Lambiase, J.J. (Ed.), Hydrocarbon Habitat in 1365 Rift Basins: Geological Society, London, Special Publication, 80, pp. 197-210. 1366

Souza-Lima, W. 2008. Sequencia evaporitica da bacia de Sergipe-Alagoas. In: Mohriak, 1367 W.U., Szatmari, P., Couto Anjos, S. (Eds.), Sal: Geologia e Tectonica. Ediçoes Beca. 1368 Petrobras, Sao Paulo, pp. 231-249. 1369

Teisserenc, P. Villemin, J. 1990. Sedimentary basin of Gabon; geology and oil systems. 1370 In: Edwards, J.D., Santogrossi, P.A. (Eds.), Divergent/Passive Margins Basins: 1371 American Association of Petroleum Geologists Memoir, 48, pp. 117-199. 1372

Torsvik, T.H., Rousee, S., Labails, C., Smethurst, M.A., 2009. A new scheme for the opening 1373 of the South Atlantic Ocean and the dissection of an Aptian salt basin. Geophysical 1374 Journal International 177, 1315-1333. 1375

Turner, S., Regelous, M., Kelley, S., Hawkesworth, C., Mantovani, M., 1994. Magmatism and 1376 continental break-up in the South Atlantic; high precision ${ }^{40} \mathrm{Ar}-{ }^{39} \mathrm{Ar}$ geochronology. 1377 Earth and Planetary Science Letters 121, 333-348. 1378

Uesugui, N., 1987. Posicao- estratigrafica- dos evaporitos da Bacia- de Sergipe Alagoas. 1379 Revista_Brasileira da_Geociências 17, 131-134. 1380

Unternehr, P., Peron-Pinvidic, G., Manatschal, G., Sutra, E., 2010. Hyper-extended crust 1381 in the South Atlantic; in search of a model. Petroleum Geoscience 16, 207-215. 1382

Viana, C.F., Gama Jr., E.G., Simoes, I.A., Moura, J.A., Fonseca, J.R., Alves, R.J., 1971. Revisao 1383 estratigrafica da bacia de recôncavo/tucano. Boletim Técnico da Petrobras 14, 1384 157-192.

Vieira, R.A.B., Mendes, M.P., Vieira, P.E., Costa, L.A.R., Tagliari, C.V., Bacelar, L.A.P., Feijo, 1386 F.J., 1994. Bacias do Espirito Santo e Mucuri. Boletim de Geociencias da Petrobras 8, 1387 191-202. 1388

Wardlaw, N.C., 1972. Unusual marine evaporites with salts of calcium and magnesium 1389 chloride in Cretaceous basins of Sergipe, Brazil. Economic Geology 67, 156-168. 1390

Wardlaw, N.C., Nicholls, G.D., 1972. Cretaceous evaporites of Brazil and West Africa and 1391 their bearing on the theory of continent separation. 24th International Geological 1392 Congress, Montréal, Section 6, pp. 43-55. 1393

Wernicke, B.P., 1985. Uniform-sense normal simple shear of the continental litho- 1394 sphere. Canadian Journal of Earth Sciences 22, 108-125. 1395

Winter, W.R., Jahnert, R.J., Franca, A.B., 2007. Bacia de Campos. Boletim de Geociencias 1396 da Petrobras 15, 511-529. 1397 da Petrobras 12, 21-86. in lithology and organic matter; tectonic and paleogeothermal evolution.

Journal of African Earth Sciences and the Middle East 10, 319-330. Boletim de Geociencias da Petrobras 15, 485-491.

Santos, C.F., Gontijo, R.C., Araujo, M.B., Feijo, F.J., 1994. Bacias de Cumuruxatiba e Jequitinhonha. Boletim de Geociencias da Petrobras 8, 185-190. 